\title{
ESTUDO DA SELEÇÃO ENTRE E DENTRO DE FAMÍLIAS DE MEIOS IRMÃOS COM SEMENTES REMANESCENTES EM DOIS COMPOSTOS DE MILHO ( $\mathscr{Z}_{e a}$ mays $\mathrm{L}$.).
}

TEREZA CRISTINA PEIXOTO

Orientador: JOÃO RUBENS ZINSLY

Dissertação apresentada à Escola Superior de Agricultura "Luiz de Queiroz", da Universidade de São Paulo, para obtenção do título de Mestre em Genética e Melhoramento de Plantas.

\footnotetext{
P I R A C C A B A

Estado de São Paulo - Brasil

Setembro - 1980
} 


\section{BIBLIOGRAFIA DO AUTOR}

Tereza Cristina Peixoto, filha de Mario Augusto Peixoto e Maria de Lourdes Fazterra Peixoto, nasceu em 19 de julho de 1953, em São Paulo, São Paulo. Em 1974 ingressou na Escola Superior de Agricultura "Luiz de Queiroz", pertencente à Universidade de são paulo. Em setembro de 1975 iniciou estā gio no Instituto de Genética, na seção de milho, sob orientação do Professor João Rubens Zinsly. Graduou-se em Engenharia Agronômica no ano de 1977, ingressando no ano seguinte no curso de pōs-graduação do Instituto de Genética da ESALQ/USP, visando a obtenção do tîtulo de Mestre em Genētica e Melhoramento de plantas. 
.iii.

$\bar{A}$

meus pais

$e$ irmãs,

DEDICO 
.iv.

"in memorian"

de

Eugenio Augusto Pinto 
- A Luiz Vicente de Queiroz, que permitiu que - sonho de muitos se realizasse.

- Ao Professor João Rubens Zinsly e sua esposa pela amizade e incentivo nos meus estudos.

- Ao Professor José Branco de Miranda Filho, pe. las valiosas críticas e sugestões; sobre tudo quanto às análises estatisticas do trabalho.

- Aos amigos Flávia Maria Oliveira, Otāvio Briganti Solferini, Teresa Lousada Vale e D. Lourdes Monteiro Mel li, que em todos os momentos estiveram presentes com uma palavra de estimulo.

- Ao amigo Antonio Roberto Cruz, pelas sugestões na revisão do manuscrito.

- Ao pessoal da República "Xodó" e agregados,pe lo incentivo e colaboração.

- Às funcionārias Terezinha de Jesus Barrete, Eiza Aparecida A. Cezar, Guerda e Erica Spruck, pela atenção.

- Aos funcionários Antonio Serrano, Paulo Razera e José Monteiro, por toda colaboração na instalação dos experimentos de campo. 
.vi.

- Ao Conselho Nacional de Pesquisa (CNPq), pela bolsa de pesquisa concedida. 
1. RESUMO $\ldots \ldots \ldots \ldots \ldots \ldots \ldots \ldots \ldots \ldots \ldots \ldots \ldots \ldots \ldots \ldots \ldots \ldots \ldots$

2. INTRODUÇÃO $\ldots \ldots \ldots \ldots \ldots \ldots \ldots \ldots \ldots \ldots \ldots \ldots \ldots \ldots \ldots \ldots \ldots$

3. REVISÃO DE LITERATURA $\ldots \ldots \ldots \ldots \ldots \ldots \ldots \ldots \ldots \ldots \ldots \ldots \ldots \ldots \ldots \ldots$

3.1. Seleção entre e dentro de famílias de meios irmãos ........................... 7

3.2. Heterose e Seleção $\ldots \ldots \ldots \ldots \ldots \ldots \ldots \ldots \ldots \ldots$

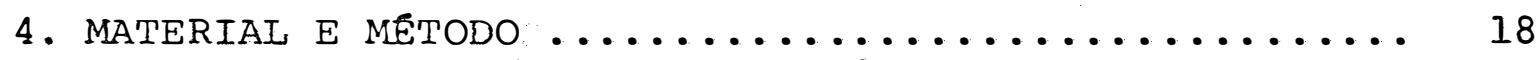

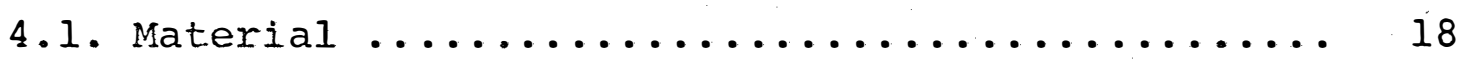

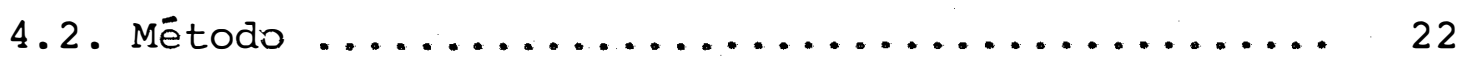

4.2.1. Procedimento ................. 22

4.2.1.1. Seleção entre famílias de meios irmãos do composto ESALQ A $\ldots . .22$

4.2.1.2. Seleção entre famílias de meios irmãos do composto ESALQ B $\ldots 22$

4.2.1.3. Seleção dentro de famílias de meios irmãos do composto ESALQ A $\ldots \ldots \ldots \ldots \ldots \ldots \ldots \ldots \ldots \ldots \ldots$

4.2.1.4. Seleção dentro de famílias de meios irmãos do composto ESALQ B .................... 24

4.2.2. Obtenção dos cruzamentos .......... 25 
viie.

pāgina.

4.2.2.1. Obtenção do cruzamento dos compostos ESALQ A original e ESALQ

B original .............. 25

4.2.2.2. Obtenção do cruzamento dos compostos ESALQ A e ESALQ B com se leção entre famílias de meios irmãos ................ 26

4.2.2.3. Obtenção do cruzamento dos compostos ESALQ A e ESALQ B com se leção dentro de familias $\cdots$ de meios irmãos ............ 26

4.2.3. Avaliação do material ........... 27

4.2.3.1. Ensaios de produção ........ 27

4.2.3.2. Coleta de dados .......... 29

4.2.3.3. Análise Estatística ........ 32

4.2.3.4. Progresso Observado ........ 34

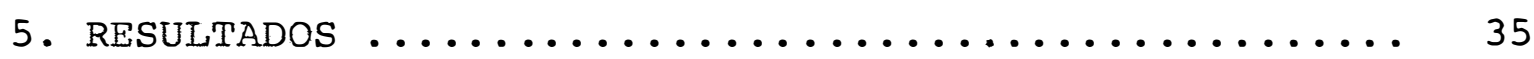

5.1. Produção $\ldots \ldots \ldots \ldots \ldots \ldots \ldots \ldots \ldots \ldots \ldots \ldots \ldots \ldots \ldots \ldots$

5.1.1. Anālise simples .............. 35

5.1.2. Análise conjunta ............. 38

5.1.3. Progresso observado .............. 39

5.2. Prolificidade $\ldots \ldots \ldots \ldots \ldots \ldots \ldots \ldots \ldots \ldots \ldots, 41$

5.2.1. Anālise simples ............... 41

5.2.2. Anālise conjunta ............. 42 
5.2.3. Progresso observado ............... 43

5.3. Acamamento ......................... 44

5.3.1. Análise simples ................. 44

5.3.2. Análise conjunta ................. 45

5.3.3. Progresso observado ............... 46

5.4. Altura de plantas ...................... 46

5.4.1. Anālise simples .................. 47

5.4.2. Análise conjunta ................ 48

5.4.3. Progresso observado .............. 48

5.5. Altura de espiga ..................... 49

5.5.1. Análise simples ................. 49

5.5.2. Análise conjunta ............... 50

5.5.3. Progresso observado ............... 50

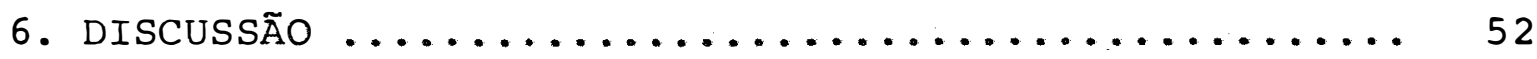

6.1. Seleção entre e dentro de famílias de meios irmãos para produção .................... 52

6.2. Seleção entre e dentro de famílias de meios irmãos para caracteres correlacionados com a pro-

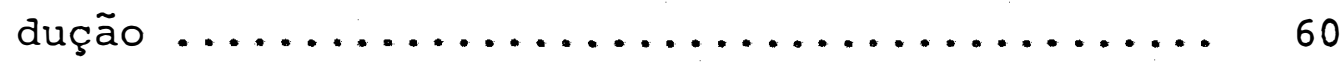

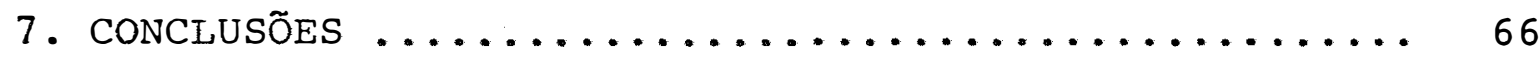

8. SUMMARY ............................. 68

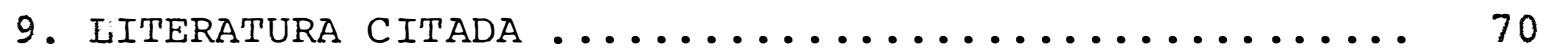

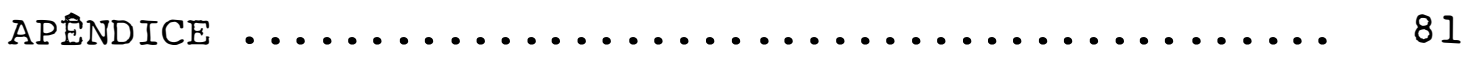


1. RESUMO

O melhoramento de populações de milho vem sendo de fundamental importância no processo preliminar de um prọ grama de híbridos. Existem vários métodos de seleção de populações, cada um com suas características. No presente trabalho realizou-se um estudo detalhado do método de seleção entre e dentro de familias de meios irmãos com sementes remanescentes.

Os materiais utilizados para esta avaliação foram os compostos ESALQ A e ESALQ B, nos estádios original, com seleção entre e com seleção entre e dentro; bem como o cruzamanto destes compostos nestes estádios, com o objetivo de ava$\because$ ar a heterose durante o processo seletivo.

As características agronômicas avaliadas foram produção, prolificidade, acamamento, altura de planta e espiga, 
sendo que maior ênfase foi dada a produção. Tais observações foram tomadas a cada estádio do processo seletivo em questão, quando se ensaiou os materiais em blocos ao acaso com nove repetições.

De acordo com os dados obtidos, verificou-se um maior progresso na produção quando se realizou seleção entre familias no ano de 1977, do que dentro de famílias no ano de 1978. Isto pode ser justificado pelo fato da seleção entre fa mílias ser realizada através de ensaios com repetições, fornecendo dados mais reais; por outro lado, sendo o método realizado com sementes remanescentes, a seleção entre é feita num ano e a seleção dentro noutro, de tal sorte que, a interação por anos pode promover dados sub ou superestimados.

Nos cruzamentos interpopulacionais observou-se um progresso crescente das populações originais para as com se leção entre e dentro. Portanto, o processo seletivo das populações contribuiu para maior divergência entre as populações, sendo esta realçada pela heterose.

Durante o ciclo de seleção entre e dentro de fa् mílias de meios irmãos não se observou diferenças significativas entre as características altura de planta e espiga, de um estádio para o outro. Pode se considerar como um fato positivo, uma vez que se processou seleção para produção sem aumen- 
tar a altura, principalmente no estádio referente a seleção en tre familias, onde se obteve certo progresso na produção. 
2. INTRODUÇAO

O melhoramento de populações de milho deu signi ficativa contribuição para a obtenção de material melhor adaptado às diversas condições ambientais. Essas populações são formadas por grande número de genótipos possuindo maior estabí lidade fenotípica do que uma população genéticamente uniforme.

Os hỉbridos de milho, obtidos de linhagens endo gâmicas, são bastante uniformes e de base genética restrita , não sendo portanto, flexiveis às variações ambientais de clima, praga e patógeno. SPRAGUE (1971), salienta, em estudo feito com cinco grupos de linhagens dos Estados Unidos, a pequena di versidade genética existente entre os híbridos comerciais por elas formados.

O melhoramento de uma população de milho tambēm conduz a uma restrição na base genética, porém uma certa varią 
bilidade sempre persiste. Alēm do aspecto positivo da manuten ção de certa variabilidade, o melhoramento de populações por ser um sistema aberto permite a introgressão de germoplasma exōtico em material adaptado.

As populações melhoradas de milho podem ser usa das como tais, de acordo com as necessidades da região, bem co mo para formação de híbridos intervarietais e como fonte de li nhagens para a obtenção de híbridos superiores. Portanto, con sidera-se os processos de obtenção de populações melhoradas e de híbrido como complementares, tendo-se maiores chances de se obter melhores híbridos através de populações melhoradas.

Existem vārios métodos de melhoramento de populações, que podem ser usados com o objetivo de se ter um progresso significativo na produção e em outros caracteres agronô micos. Todos estes métodos baseiam-se, fundamentalmente, na utilização dos efeitos genéticos aditivos, envolvendo tambēm a recombinação dos melhores indivíduos das famílias, com base na avaliação ġenotípica e fenotípica. o objetivo principal é o aumento da frequência de alelos favorāveis e criar condições para a obtenção de linhagens superiores. As diferenças existentes entre esses métodos referem-se principalmente ao grau de parentesco dos progenitores selecionados, existência ou não de avaliação de progênies e controle de ambiente.

o objetivo deste trabalho é o estudo da seleção entre e dentro de famílias de meios irmãos, bem como os efei- 
tos da seleção entre e seleção entre e dentro, avaliando-se também os cruzamentos em todos os passos de um ciclo se seleção, para as características produção, prolificidade, acamamen to, altura de planta e espiga. 


\section{REVISATO DE LITERATURA}

3.1. Seleção entre e dentro de famîlias de meios irmãos

Louis de Vilmorin em 1843, trabalhando com beterraba percebeu que as raízes de alto teor de açúcar podiam dar descendentes de alto e baixo teor. Verificou que melhores informações a respeito do valor genético de uma planta são obtidas através do estudo de sua descendência, e não atravēs da avaliação fenotípica individual. Baseado nessas observações, criou o método de seleção, que è conhecido como "Princípio do Isolamento" ou "Método de Vilmorin". Este consiste, es sencialmente, em avaliar as progênies de raízes de beterraba e selecionar aquelas que apresentam descendência com alto teor de açücar.

o sucesso do método de Vilmorin induziu pesquisadores dos Estados Unidos da América a usarem processo similar no melhoramento de milho, denominando-o espiga por fileira 
(ear-to-yow), o qual foi relatado por Hopkins em 1896 (Hopkins, 1899, apud SPRAGUE, 1955). O autor aplicou este método na variedade de milho Burr White, com objetivo de modificar o teor de óleo e proteína do grão de milho.

o método espiga por fileira foi também utilizado para promover o melhoramento de outros caracteres, e mostrou-se eficiente para melhorar caracteres qualitativos; no en tanto, apresentou resultados desanimadores para caracteres quantitativos. Com a finalidade de torná-lo mais eficiente pa ra produtividade, que é um carāter quantitativo, várias modifi cações foram feitas no método original. RICHEY (1922), apresenta uma revisão sobre as técnicas introduzidas no método, com o objetivo principal de reduzir o erro experimental, possi bilitando assim, comparações mais precisas entre as progênies. Neste trabalho, também são apresentados os resultados obtidos por vários pesquisadores, demonstrando as vantagens e desvanta gens do método para o caráter produtividade.

O trabalho de Smith e Brunson (1925, apud SPRAGUE, 1955), apresenta comparações mais consistentes da seleção espiga por fileira, chegando a resultados mais concludentes . Os autores aplicaram o método espiga por fileira em 990 espigas selecionadas de uma variedade local de Illinois. As populações originais foram mantidas em lote isolado, para servirem de parâmetro de comparação. Após cinco ciclos, as populações selecionadas foram comparadas com as populações originais e 
com a testemunha Reid Yellow Dent, em ensaios de produção por dez anos. Os resultados demonstraram que a seleção foi ineficiente para aumentar a produtividade, uma vez que as populações melhoradas não diferiram da testemunha e nem das populações originais. De posse desses resultados, os autores concluiram que o método espiga por fileira não era recomendado pa ra promover melhoramento de produtividade. Devido a esses fatos desanimadores, o mētodo foi abandonado, embora SPRAGUE (1955) afirmasse que este malogro não se devia a limitações ge néticas e sim à técnica experimental inadequada.

ROBINSON et alii (1955), estudando em milho estrutura genētica de populações de polinização aberta, demons traram a existência de alta variabilidade genētica aditiva entre essas populações. Fato este confirmado posteriormente por resultados de vários trabalhos; o que contribuiu para provar que o emprego de tēcnica experimental deficiente foi a principal causa do insucesso do método de seleção espiga por fileira para produtividade.

Tudo indicava que os métodos de seleção intrapo pulacionais eram bastante eficientes para melhorar a produtivi dade; no entanto, era preciso que fossem revistos com a finali dade de se reduzir o efeito ambiental. Com base nessas observações, LONNQUIST (1960) introduziu uma modificação no mētodo de seleção massal, de tal sorte que a seleção entre plantas se ria efetuada dentro de estratos do campo experimental. Com es 
ta modificação o método passou a ser conhecido por seleção mas sal estratificada. GARDNER (1961) apresentou resultados satis fatórios, mostrando que esta modificação promoveu substancial eficiência ao método na seleção para produtividade; os progres sos obtidos após quatro ciclos foram de $3,93 \%$ por ciclo de seleção. Em publicação posterior, GARDNER (1973) apresentou resultados de 17 ciclos de seleção massal estratificada na varie dade Hays Golden, evidenciando um ganho contínuo de $3 \%$ por ciclo de seleção.

Como consequência desses fatos, LONNQUIST (1964) introduziu, no método espiga por fileira uma modificação no sentido de se utilizar delineamentos experimentais, promover um maior controle da polinização e amostragem de sementes mais representativa. O método passou a ser denominado espiga por fileira modificado e, basicamente este consiste na avaliação de progênies de milho em ensaios de produção, colocando-se repetições, uma em cada local. A seleção entre progênies é feita com base na média dos resultados das repetições, enquanto que a seleção dentro das progênies é feita visualmente (seleção massal), num dos locais. Nesta repetições o material é plantado em lote isolado de despondoamento, com quatro fileiras femininas e duas masculinas; correspondendo as fileiras fe mininas às progênies dos ensaios, e as masculinas a uma mistura homogênea das sementes das progênies. O Indice de seleção entre progênies é de $20 \%$ e na seleção dentro é de $10 \%$, sendo 
coletadas as espigas das cinco melhores plantas nas progênies selecionadas.

O método espiga por fileira modificado (LONNQUIST; 1964), apresentou aumentos de produtividade, sem contudo, contribuir para elevar a taxa de endogamia; mostrando-se geneticamente promissor, dispensando polinizações manuais e ne cessitando apenas de ensaios com repetições e lote isolado.Des ta forma, as modificações propostas tiveram aceitação geral, e - método foi adotado por alguns países na condução de programas de melhoramento.

PATERNIANI (1967), aplicando o método de seleção espiga por fileira modificado, publicou os primeiros resul tados, que indicaram um progresso médio de 13,6\%, por ciclo,ao avaliar três ciclos de seleção para produtividade. 0 autor passou a denominar o método de "Seleção entre e dentro de famí lias de meios irmãos", e introduziu pequenas modificações no método, tornando-o mais viável e possibilitando a obtenção de um ciclo de seleção por ano.

WEBEL e LONNQUIST (1967), aplicando o método de seleção espiga por fileira modificado na variedade Hays Golden, confinmaram a efetividade do método de seleção para produção de grãos, obtendo um progresso médio de 9,44\% por ciclo, durante quatro ciclos. Este resultado foi superior ao encontrado por LONNQUIST (1967), ao aplicar seleção massal estratificada para prolificidade na mesma variedade. COMPTON e BAHADUR (1977),pu 
blicaram dados referentes a mesma população com dez ciclos de seleção, apresentando um progresso médio por ciclo de 5,26\% em relação à população original. Embora o progresso médio por cí clo de seleção tenha sido bastante reduzido, este método promo veu melhores ganhos que os apresentados por GARDNER (1973), ao aplicar o método de seleção massal estratificada na mesma popu lação de milho.

PATERNIANI (1968a) promoveu quatro ciclos de se leção entre e dentró de famílias de meios irmãos no milho Pira mex e um ciclo no milho Centralmex, obtendo progressos por ciclo de 3,88 e 3,38 , respectivamente. O autor afirma que o método não só foi eficiente para aumentar a produtividade, como também para aumentar a capacidade de combinação nos cruzamentos envolvendo populações de milho melhoradas. Admite ainda que, o esquema utilizado resultou em sensível diminuição da va riabilidade genética da população original para o primeiro ciclo, mantendo-se a partir deste, mais ou menos estável. No en tanto, progressos contínuos foram obtidos nos ciclos subsequen tes.

Fazendo um estudo comparativo entre seleção mas sal e seleção entre e dentro de famílias de meios irmãos, nas populações Dente Paulista, Caingang e Cateto, ZINSLY (1969) ob teve um progresso duas vezes superior para a seleção entre e dentro de famílias de meios irmãos. PEIXOTO e ZINSLY (1979), comparando os progressos destas populações com seleção entre e 
com seleção entre e dentro de progênies, os consideraram semelhantes, levando-se em conta a facilidade na prática da seleção dentro de progênies.

Trabalhos utilizando o mētodo de seleção entre e dentro de famílias de meios irmãos com sementes remanescentes, foram realizados por SUAREZ LEZCANO (1976), no Composto Flint Branco, por CUNHA (1976) no milho ESALQ-HV-l, por WINKLER (1977) no Composto Dentado Branco e por LIMA (1977) no mi Iho ESALQ-VD-2. Todos detectaram progresso no método de seleção entre e dentro de famílias de meios irmãos com sementes remanescentes, obtendo-se um ciclo a cada dois anos.

\subsection{Heterose e Seleção}

Em 1877, Charles Darwin, avaliando altura de plantas, apresentou os primeiros dados comparativos de plantas cruzadas e autofecundadas de um mesmo material. Os trabalhos de EAST (1908) e SHULL (1909) trouxeram nova contribuição ao estudo dos efeitos de endogamia e de vigor de híbridos nos crü zamentos. Este acontecimento apenas alcançou uma nova dimensão depois que JONES (1918) sugeriu o cruzamento entre dois hí bridos simples, resultando num híbrido duplo, o que tornou pos sível a produção de sementes híbridas em escala comercial. Por um período de vinte anos, a maioria dos melhoristas passaram a se dedicar ao método do milho híbrido. Depois de certo tempo, 
notou-se grande preocupação entre eles, pois os seus esforços não eram compensados por um aumento satisfatório na produtividade. Foram sugeridos vários esquemas para obtenção de linhą gens endogâmicas, entretanto, os resultados não foram os esperados e o insucesso foi explicado como sendo devido à baixa frequência de genes favoráveis nas populações originais dessas linhagens. Baseado nisto, justificou-se, como medida preliminar de um programa de milho híbrido, se promover um melhoramen to de populações para se elevar a frequência de genes favoráveis.

Por outro lado, justificou-se também, aproveitar de maneira mais dirigida a heterose dos cruzamentos. Para tanto, fazendo um-breve relato dos trabalhos encontrados na li teratura, tem-se que Beal (1877, apud SPRAGUE, 1955) apresentou os primeiros dados a respeito de cruzamentos intervarietais em milho, realçando a existência de vigor de híbrido nos cruzamentos. Também RICKEY (1922) apresentou dados comparativos entre produção de variedades e seus híbridos $F_{1}$, onde obte ve grande parte dos cruzamentos superiores à média dos pais e parte excedeu o pai mais produtivo. Contribuição importante neste sentido, foi dada por SPRAGUE e TATUM (1942), quando estabeleceram conceitos a respeito de capacidade geral e especifica de combinação, permitindo que métodos de análise de cruza mentos dialélicos fossem desenvolvidos. Assim, GRIFFING (1956 a e 1956b), apresentou um método de análise de variância para 
estimação dos parâmetros de capacidade geral e específica de combinação em cruzamentos dialélicos, de acordo com dois modelos: fixo e aleatório. GARDNER e EVERHART (1966), fazendo crú zamentos dialélicos entre seis variedades $\left(v_{j}\right)$ e para heterose média $(\bar{h})$, mostraram que as variedades diferem entre si quando avaliadas per se, mas não diferindo quanto ao seu potencial he terótico nos cruzamentos.

Com o objetivo de obter melhores genótipos para máxima heterose, independente dos tipos de ação gênica envolvị dos, COMSTOCK et alii (1940) sugeriram o esquema de seleção re corrente reciproca. Dados de COLLIER (1959) e DOUGLAS et alii (1961) indicam eficiência relativa ou parcial deste método de seleção. Os resultados encontrados nem sempre coincidem com os esperados teoricamente, pois ganhos obtidos com a seleção não foram eficientes para elevar a heterose dos cruzamentos.

Trabalhando com cinco populações de milho, LONN QUIST (1961) realizou três ciclos de seleção recorrente para capacidade geral de combinação e, efetuando os respectivos crü zamentos, não detectou variação na heterose. Da mesma forma MOLL e ROBINSON (1967) encontraram uma heterose constante, em váxios cruzamentos de gerações avançadas, nas variedades Jare Indian Chief.

Estudando a heterose média dos cruzamentos enC variedades de uma mesma região, MOLL et alii (1962) concluiram que a heterose, em relação a média dos pais aumenta com 
o acréscimo da diversidade genética. Em estudo posterior,MOLL et alii. (1965) admitiram que acréscimos constantes de diversidade genética podem, eventualmente, tornarem-se suficientemente grande, a ponto de causarem desequilíbrio gênico, reduzindo a heterose manifestada nos cruzamentos.

O trabalho de MOLL e ROBINSON (1966) admite a eficiência relativa do método de seleção recorrente recíproca, nas populações Indian Chief e Jarvis, por três ciclos. Cruzan do-se entre os respectivos ciclos, observaram que a heterose aumentou do original para o segundo ciclo e decaiu no segundo. No entanto, PATERNIANI (1969), realizando três ciclos de seleção entre e dentro de famílias de meios irmãos nas populações Dente Paulista e Piramex e, fazendo cruzamentos interpopulacio nais a cada ciclo, verificou que houve aumento da heterose com a seleção. Porēm, PATERNIANI (1971), empregando seleção recor rente recíproca com plantas prolificas nas populações de milho Dentado Composto e Flint Composto originais, encontrou pouca variação de heterose, aumentando apenas em $0,6 \%$ em relação aos cruzamentos originais.

VALOIS (1973), estudando o efeito da seleção mas sal estratificada sobre as populações de milhos Dente Paulista e Cateto Minas Gerais e, principalmente, sobre os híbridos obtidos do intercruzamento das mesmas por vários ciclos de seleção, concluiu que a seleção recorrente intrapopulacional refle tiu negativamente sobre a produção de grãos do híbrido interpo 
pulacional em ciclos de seleção mais avançados. O autor também considerou que a seleção intrapopulacional, aplicada em duas populações, não pode ser considerada como garantia para reter a heterose inicial entre elas. Assim, se esse tipo de seleção alterar a frrequência dos genes com alguma dominância, ela poderá levar a uma redução da heterose, o que não é favorá vel para os interesses do melhorista. 


\section{MATERIAL E METODO}

\subsection{Material}

Foram utilizadas populações dos compostos ESALQ A e ESALQ B em diferentes estádios do método de seleção entre e dentro de famílias de meios irmãos e seus respectivos cruzamentos, a saber: composto ESALQ A e ESALQ B originais; com seleção entre; com seleção entre e dentro e os cruzamentos inter populacionais destas etapas.

Os compostos ESALQ A e ESALQ B foram sintetizados no Instituto de Genética da Escola Superior de Agricultura "Luiz de Queiroz", Universidade de são Paulo, segundo a metodo logia proposta por EBERHART et alii (1967). São constituídos, basicamente, por germoplasma Tuxpeño e Flint de origens Mexica na, Cubana e Colombiana. Foram sintetizados com o objetivo principal de melhor explorar a variabilidade existente nas di- 
ferentes raças e variedades, possibilitando assim maior progresso por seleção para os diversos caracteres.

Estes compostos foram sintetizados a partir de dez populações de milho, que pertenciam ao banco de germoplasma do Instituto de Genética; sendo que o composto ESALQ A foi obtido pela combinação dos germoplasmas WP4, WP7, WP25 e o com posto ESALQ B pelas populações WP11, WP12, WP17, WP24, WP33, WP34 e Piracar. A seguir é apresentada uma breve descrição destas populações, de acordo com PATERNIANI (1968b).

WP4 - Tipo de grão duro branco, originārio da Colombia, obtido pelo cruzamento entre Nariño 330 x Peru 330 .

WPP - Eto Blanco: variedade de milho flint bran co, obtido na Colombia.

WP25 - La Posta: tipo de grão dentado branco. Sintētico de alta produtividade, Tuxpeño branco.

WP11 - Porto Rico Grupo 2: tipo de grão amarelo semi-dentado, originārio de Porto Rico.

WP12 - Composto meio duro, de grãos amarelos. Compreende uma das melhores coleções intervarietais de flints e meio flint com dentados (Tuxpeño). 
WP17 - Antigua Grupo 2: meio flint amarelo, plantas baixas, precoces, prolíficas; parecem ter resistência a Laphygma e apresentam alta capacidade de combinação com Tuxpeño. E originārio do Caribe.

WP24 - PD (MS) 6: flint amarelo de Cuba, obtido por seleção massal, originārio de Cuba.

WP33 - Amarillo Salvadorenho: tipo de grão meio dente amarelo, originārio de El Salvador.

WP34 - Sintético da Flórida: tipo de grão meio dente amarelo, originārio dos Estados Unidos da América do Nor te.

Piracar - Flint laranka, espigas curtas e relativamente cônicas. Período de florescimento em torno de 70 dias, proveniente do México, onde foi obtido pela combinação de 20 linhagens $\mathrm{S}_{1}$.

Estas populações bases foram cruzadas em dialélico no ano agrícola de $1968 / 69$ e ensaiadas com os 45 cruzamen ius interpopulacionais no ano de $1969 / 70$ em nove repetições, m "latice square" (VENCOYSKY et alii, 197la).

No ano seguinte à elaboração do dialético entre 
as populações, estabeleceram-se dois lotes isolados de recombi nação. Este processo findou-se em 1971/72 atingindo-se a homo geinização em $F_{5}$ (VENCOVSKY et alii, 197lb).

De acordo com MORO et alii (1974), no áno agrícola de 1972/73 iniciou-se com os dois compostos um ciclo de seleção recorrente recíproca com famílias de irmãos germanos. Na colheita selecionaram-se as espigas autofecundadas das popu lações $S_{1} A$ e $S_{1} B$, que apresentabam um minimo de 50 sementes; da mesma maneira, nas espigas dos cruzamentos, apenas foram se lecionadas as que apresentavam um minimo de 150 sementes. Esta seleção resultou numa soma de 297 espigas $S_{1} A$ e $S_{1} B$ lautofe cundadas) e 297 espigas $S_{0} \times S_{O}$ (cruzadas). No ano agrícola de 1973/74, as 297 progênies de irmãos germanos $s_{0} x s_{0}$ foram ensaiadas em látice, o que permitiu a seleção das 60 melhores progênies, com base numa intensidade de seleção de $20,2 \%$. As populações de I ciclo foram obtidas no ano de 1974/75 com a re combinação, em lote isolado, dos $60 \mathrm{~s}_{1} \mathrm{~A}$ e $60 \mathrm{~s}_{1} \mathrm{~B}$.

No ano seguinte o material sofreu um ciclo de seleção massal, obtendo-se, finalmente, 632 progênies para o composto ESALQ A e 660 para o composto ESALQ B, que se constituiram nas duas populações de primeiro ciclo, resultantes do I ciclo de seleção recorrente recíproca de famỉlias de irmãos germanos, mais um ciclo de seleção massal (ICSRRFIG + ICSM).Ẹ tas populações foram consideradas como originais, no presente trabalho. 
4.2. Método

\subsubsection{Procedimento}

O método usado foi o de seleção entre e dentro de famílias de meios irmãos, com sementes remanescentes, iniciado com populações originais dos compostos ESALQ A e ESALQ B.

4.2.1.1. Seleção entre famîlias de meios irmãos do composto ESALQ A

No ano agrícola de 1976/77, 632 famílias de meios irmãos do composto ESALQ A foram ensaiadas com o objetivo de se obter dados para se praticar uma seleção entre as famillias de meios irmãos. Estas familias foram avaliadas através da produção per se em comparação com a produção média do híbrido Hmd 7974 intercalado a cada 5 progênies (SOUZA JUNIOR et alii, 1978). Destas progênies; cem tambēm foram avaliadas por CRISÓSTOMO (1978), que as instalou em latice triplo $10 \mathrm{x}$ 10. Portanto, a avaliação final destas progênies baseou-se nes tes dois experimentos.

4.2.1.2. Seleção entre famîlias de meios irmãos dos compostos ESALQ B

No ano agrícola de 1976/77, 660 familias de 
meios irmãos do composto ESALQ B foram ensaiadas com a finalidade de se selecionar as melhores progênies, com base na produ ção de grãos. A metodologia seguida, para selecionar as melho res progênies do composto ESALQ B, foi a mesma aplicada na seleção entre famílias de meios irmãos do composto ESALQ A.

4.2.1.3. Seleção dentro de famīlias de meios ir mãos do composto ESALQ A

O material resultante da seleção entre famílias de meios irmãos no composto ESALQ A corresponde a 37 progênies, resultantes de uma intensidade de seleção de $6 \%$.

No ano de $1977 / 78$, as progênies selecionadas f으 ram instaladas em campo isolado de recombinação, a partir de sementes remanescentes. Os objetivos desta etapa eram de se praticar uma seleção dentro das progênies e também promover a recombinação do material proveniente da seleção entre familias de meios irmãos. Para tanto, as progênies foram despendoadas e polinizadas por linhas de macho, que eram compostos por uma mistura das 37 melhores progênies.

Na colheita executou-se a seleção massal dentro das familias de meios irmãos do composto ESALQ A, de tal forma que, foram selecionadas as 5 melhores plantas de cada familia e coletada suas espigas. Da mistura das sementes das 5 melhores plantas de cada progênie obteve-se o composto ESALQ A com 
seleção entre e dentro de familias de meios irmãos.

Apenas duas linhas de macho foram totalmente co letadas, as quais compunham o composto ESALQ A com seleção entre famílias de meios irmãos, recombinado.

4.2.1.4. Seleção dentro de famîlias de meios ir mãos do composto ESALQ B

Após a seleção entre famĩlias de meios irmãos, praticada no composto ESALQ B, obtiveram-se 39 melhores progênies, portanto a intensidade de seleção foi em torno de $6 \%$. No ano de 1977/78, a partir de sementes remanescentes, foram semeadas as melhores progênies, com a finalidade de praticar seleção massal dentro das progênies e também promover a recombinação do material oriundo da seleção entre famílias de meíos irmãos.

Por ocasião da colheita, foram selecionadas as 5 melhores plantas e coletadas suas espigas. Cada progênie era, agora, representada pela mistura das sementes obtidas des tas espigas e constituiam o composto ESALQ B com seleção entre e dentro de famílias de meios irmãos.

De acordo com o método, as 39 melhores progênies ao serem recombinadas, foram polinizadas por linhas de ma cho constituidos da mistura dessas progênies. Duas dessas linhas de macho foram coletadas, e estas sementes representavam 
- composto ESALQ B com seleção entre famílias de meios irmãos, jā recombinado.

\subsubsection{Obtenção dos cruzamentos}

Para uma avaliação da heterose existente entre as populações, a cada estádio do método de seleção entre e den tro de famílias de meios irmãos, foram necessários cruzamentos interpopulacionais dos compostos ESALQ A e ESALQ B nos respectivos estāios.

4.2.2.1: Obtenção do cruzamento dos compostos ESALQ A original e ESALQ B original

No ano agrícola de $1977 / 78$, foram instalados,em lotes paralelos, os compostos ESALQ A e ESALQ B originais e, por ocasião do florescimento, estes compostos foram cruzados e multiplicados manualmente.

o cruzamento foi feito para que nos ensaios se avaliasse a heterose existente no material original, para se poder comparar com as demais obtidas nos outros estádios. A multiplicação do material foi estabelecida para se contar com sementes da mesma idade, objetivando com isso minimizar os pro blemas de germinação e vigor de sementes, permitindo melhor comparação ao se instalar o ensaio de produção, onde se ava- 
liou o material em cada estádio do método de seleção entre e dentro de famílias de meios irmãos.

4.2.2.2. Obtenção dos cruzamentos dos compostos ESALQ A e ESALQ B com seleção entre fá mîlias de meios irmãos

No ano de 1977/78, ao mesmo tempo que se instalou no campo, em lote isolado, as progênies selecionadas do composto ESALQ B, para serem recombinados e sofrerem seleção massal, foram semeadas duas linhas do composto ESALQ A, formado de uma amostra equitativa das 37 progênies anteriormente se lecionadas. Estas duas linhas foram despendoadas e cruzadas com as melhores progênies do composto-ESALQ B.

4.2.2.3. Obtenção do cruzamento dos compostos ESALQ A e ESALQ B com seleção dentro de famîlias de meios irmãos

As sementes provenientes das 5 melhores plantas de cada progènie correspondiam ao material com um ciclo de seleção entre e dentro de familias de meios irmãos, em ambos os compostos.

Este material foi obtido em março de 1978, e em. junho de 1978 foram semeados com o objetivo de se processar a recombinação e o cruzamento destes compostos. Em fins de outu彑 
bro de 1978, este material foi coletado, debulhado e misturado, dando origem ao material com seleção entre e dentro de famílias de meios irmãos recombinado, e ao cruzamento dos dois com postos.

$$
\text { Portanto, para se abreviar o processo, foram }
$$

realizados dois ciclos num ano, e assim, o ensaio de produção para avaliação de todas etapas de um ciclo de seleção entre e dentro de famílias de meios irmãos, pode ser realizado no seguinte ano agrícola.

\subsubsection{Avaliação do material}

\subsubsection{Ensaios de produção}

O delineamento experimental empregado para avaliar os efeitos obtidos a cada estádio do mētodo de seleção en tre e dentro de famílias de meios irmãos, foi o de blocos ao acaso com nove repetições. Os ensaios de produção foram insta lados em dois locais: um em Agua Santa, município de Piracicaba e outro em Anhumas, município de Piracicaba, no ano agrícola de $1978 / 79$

Nos dois ensaios, de Aggua Santa e Anhumas, contou-se com os seguintes tratamentos:

- Ao - composto ESALQ A original 
- Bo - composto ESALQ B original

- AOBO - cruzamento dos compostos ESALQ A e ESALQ B originais.

- Ae - composto ESALQ A com seleção entre famílias de meios irmãos.

- Be - composto ESALQ B com seleção entre famílias de meios irmãos

- AeBe - cruzamento dos compostos ESALQ A e ESALQ B com seleção entre famílias de meios irmãos

- Aed - composto ESALQ A com seleção entre e dentro de famílias de meios irmãos

- Bed - composto ESALQ B com seleção entre e dentro de famílias de meios irmãos

- AedBed - cruzamento dos compostos ESALQ A e ESALQ B com seleção entre e dentrode famílias de meios irmãos

- Cargill-1ll

- Cargill-5005

$-\operatorname{Ag} 259$

Os ensaios foram instalados com um intervalo de 10 dias, para que houvesse melhor desempenho no trabalho de co leta dos dados. Nos dois experimentos, as parcelas eram repre sentadas por uma linha de 10 metros de comprimento, com espaça mento entre linha de um metro e entre plantas de 0,40 metros. 
Foram colocadas 75 sementes por parcela, sendo três sementes por cova. Após 15 dias, as linhas foram desbastadas, deixando - se duas plantas por cova e, portanto, cada parcela completa era constituida de 50 plantas.

Devido às condições adversas de pluviosidade, o ensaio conduzido em Anhumas foi irrigado durante o florescimen to.

\subsubsection{Coleta de dados}

Foram feitas coletas de dados referentes a produção de grãos, altura de plantas, altura de espiga, acamamento e prolificidade. A maneira como foram coletados todos estes dados será descrita sumariamente.

A. DADOS DE ALTURA DE PLANTA

Foram anotados os dados referentes à altura de 10 plantas ao acaso de cada parcela. Esta medida (em metros) foi feita com uma régua colocada do solo até a inserção da ūltima folha.

B. DADOS DE ALTURA DE ESPIGA

Nas mesmas plantas onde se obtiveram os dados referentes à altura de planta, foram retirados os dados de altura de espiga. Portanto, foram coletados 10 dados por parcela. Esta medida (em metros) foi feita do solo até a inserção da primeira espiga. 
C. DADOS DE ACAMAMENTO

Antes da colheita, realizou-se a contagem do nū mero de plantas acamadas por parcela. Considerou-se acamada a planta com uma inclinação inferior a $30^{\circ}$.

D. DADOS DE PROLIFICIDADE

Os dados de prolificidade foram obtidos mediante a contagem do número de plantas por parcela que apresentavam mais de uma espiga.

E. DADOS DE PRODUCẼO

Os dados de produção são obtidos a partir de um conjunto de informações, a saber: "stand" final; peso de semen tes e teor de umidade.

1. "stand" final - antes da colheita realizou-se uma contagem do número de plantas existentes em cada parce la.

2. peso das sementes - após a pesagem das espigas, estas foram debulhadas e em seguida obteve-se o peso das sementes. Os dados de produção de sementes foram anotados em quilograma.

3. teor de umidade - coletou-se uma amostra de $100 \mathrm{~g}$ de sementes de cada parcela; estas foram mantidas numa lata impermeável por um período minimo de 24 horas, para que se processasse a homogeinização do material. As determinações 
de umidade foram feitas com o auxilio do aparelho steinlite Tester, modelo G.

Os dados referentes a peso de sementes foram corrigidos para umidade e "stand". O teor de umidade foi ajus tado para 15,5\%, constante para todas as parcelas de acordo com a fórmula:

$$
\mathrm{PC}_{15,5 \%}=\frac{\mathrm{P} \cdot \mathrm{C} \cdot(1-U)}{(1-0,155)}
$$

sendo:

$$
\begin{aligned}
& \mathrm{PC}_{15,5 \%}=\text { peso de campo corrigido para } 15,5 \% \text { de } \\
& \text { P.C. = peso de campo observado; } \\
& \text { U } \quad \text { = umidade de campo observada. }
\end{aligned}
$$
plantas por parcela, e as parcelas que não apresentavam este nümero foram corrigidas de acordo com a fórmula de ZUBER(1942):

$$
\text { P.C.C. }=P_{15,5 \%} \times \frac{H-0,3 F}{H-F}
$$

sendo:

$$
\begin{aligned}
& \text { P.C.C. = } \\
& \text { umidade e "stand" ideal de umidade; } \\
& \text { H = "stand" ideal (50 plantas por parcela); } \\
& \begin{aligned}
\text { P.C. } 15,5 \% & \text { peso de campo corrigido para } 15,5 \% \\
& \text { de umidade; }
\end{aligned}
\end{aligned}
$$


$F=$ nümero de falhas.

Este ajuste para "stand" ideal acrescenta 0,7 de produção média de parcela para cada falha (planta não sobre vivente), considerando que 0,3 da sua produção é recuperada pe lo aumento na produção das plantas vizinhas.

\subsubsection{Anālise Estatistica}

Realizou-se a anālise da variância dos dados de produção, corrigidos para "stand" e umidade; altura de planta; altura de espiga; prolificidade e acamamento.

A anālise da variância foi feita de acordo com o delineamento de blocos ao acaso, analisando-se os dois experimentos individualmente para cada característica observada em Agua Santa e em Anhumas.

Posteriormente, processou-se a anālise conjunta, envolvendo os dois locais para as caracteristicas catalogadas. Os dados de ariálise conjunta foram testados com o resíduo, uma vez que os efeitos foram considerados fixos.

Para avaliar as diferenças existentes entre os tratamentos, procedeu-se o desdobramento dos graus de liberdade, como mostra a tabela 1 . 
Tabela 1. Quadro parcial da análise da variância com desdobramento dos graus de liberdade de tratamentos.

F.V.

G.I.

Tratamentos

11

Populações

8

Seleções A

2

Seleções B

2

Seleções AB

2

Entre grupos

2

Testemunhas

Populações "versus" testemunhas

Os tratamentos são em nümero de 12, ou seja, três estādios de seleções A (original, entre e entre e dentro), três estádios de seleções B (original, entre e entre e dentro), e três estādios de seleções AB (original, entre e entre e dentro) e 3 híbridos comerciais. Portanto, ll são os seus graus đe liberdade, os quais são desdobrados em 8 graus de liberdade Ha as populações, 2 graus de liberdade para testemunhas, e 1 au de liberdade para as populações "versus" testemunhas.

As populações são em nūmero de 9 , a saber: 


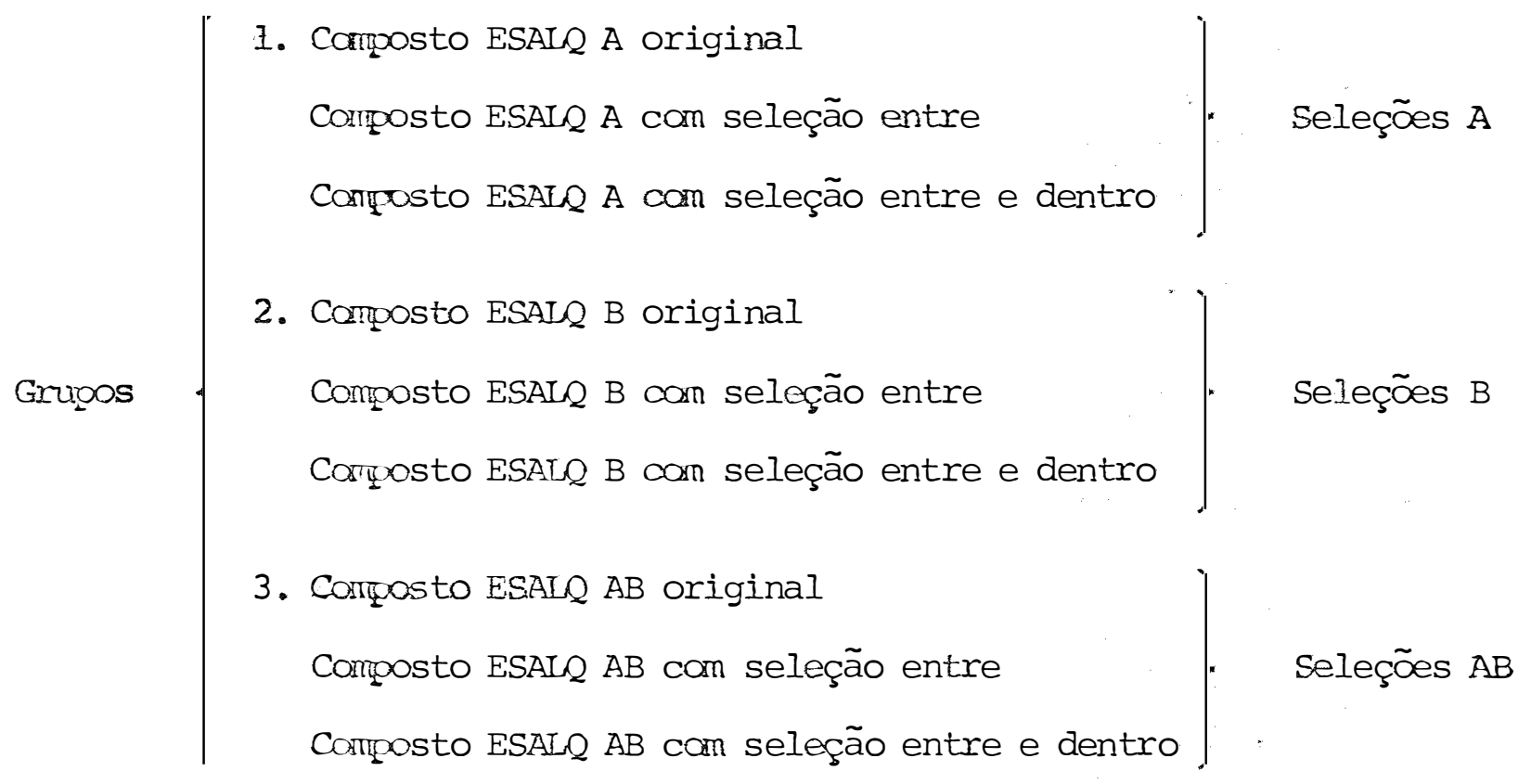

Observa-se que existem 3 grupos, os quais incluem as seleções $A$, seleções $B$ e seleções AB. Apōs esta esplanação, fica claro observar como foi feito o desdobramento dos graus de liberdade de populações.

\subsubsection{Progresso observado}

De acordo com os dados médios observados, na análise individual e conjunta, foi avaliado o progresso obtido ao se passar de um estádio para o outro do método de seleção entre e dentro de familias de meios irmãos, bem como a avaliação de heterose dos compostos a cada etapa de seleção. 
.35 .

5. RESULTADOS

5.1. Produção

Das caracteristicas observadas, foi dado enfase à produção, visto ser o caráter fundamental na direção de um programa de melhoramento.

5.1.1. Anālise simples

De acordo com o exposto em tópico anterior, os ensaios foram realizados em dois locais, a saber: Água Santa e Anhumas. Neste ítem se discorrerá sobre os resultados individuais obtidos em cada local.

A tabela 2 contem os dados de produção obtidos em Agua Santa. Os dados são referentes ao experimento em blo- 
cos ao acaso em nove repetições. Nesta tabela tambēm sã citados os dados de produção média por tratamento, a qual variou en tre $4,36 \mathrm{~kg} / 10 \mathrm{~m}^{2}$ a $5,29 \mathrm{~kg} / 10 \mathrm{~m}^{2}$ (excluindo-se as testemunhas).

A tabela 12 apresenta a análise de variância des tes dados, segundo delineamento em blocos ao acaso (PIMENTEL GOMES, 1976) do material referente aos estádios do processo se letivo de famílias de meios irmãos dos compostos ESALQ A e ESALQ B. De acordo com a anālise, a média do experimento foi de $4,78 \mathrm{~kg} / 10 \mathrm{~m}^{2}$, com um coeficiente de variação igual a 17,3\%, considerando aceitável por se tratar de um ano com muita seca, e por outro Iado, são semelhantes aos encontrados na literatura. Para os tratamentos, o teste $\mathrm{F}$ foi significativo a nível de 1\% de probabilidade. Aplicando-se o teste Tukey, a nível de 5 e lo de probabilidade, não foi possível se detectar diferenças significativas entre as médias.

Os trabalhos tiveram os seus graus de liberdade desdobrados em: entre seleções $A$; entre seleções $B$; entre sele ções $\mathrm{AB}$ e entre grupos. Os dädos referentes a esse desdobramento encontra-se descritos na tabela 14. Aplicando-se o teste $F$, observa-se que as diferenças são significativas a nível de 1\% de probabilidade, na avaliação das testemunhas e para po pulações "versus" testemunhas; a nível de 5\%, detectou-se dife renças entre os grupos, demonstrando que a significancia de 1\% para os tratamentos são devidos, em grande parte, às testemunhas. 
Os dados de produção, por parcela de $10 \mathrm{~m}^{2}$, referente ao ensaio realizado em Anhumas, encontram-se na tabela 3, onde também são citadas as produções médias por tratamento, que variaram entre 3,84 a $4,64 \mathrm{~kg} / 10 \mathrm{~m}^{2}$ (excluindo-se as teste munhas) •

Com esses dados foi feita a análise de variância do material resultante nos estádios de seleção entre e den tro de famílias de meios irmãos para os compostos ESALQ A e ESALQ B e de acordo com os dados da tabela 13, a média do expe rimento toi de $4,37 \mathrm{~kg} / 10 \mathrm{~m}^{2}$ e o coeficiente de variação foi de 19,5\%. Embora o ensaio de Anhumas não tivesse sofrido muito com a seca, pois foi irrigado, o seu coeficiente de variação foi um pouco superior ao de Água santa. Isto pode ser jus tificado por uma possível desuniformidade na irrigação, provo cańdo com isso uma maior discordância entre os dados.

De acordo com os dados da tabela 17, tem-se: pa ra as seleções $A$ um progresso de 4,6\% para as populações com seleção entre familias de meios irmãos e 0,2\% para as mesmas populações com seleção entre e dentro de famílias de meios irmãos; as seleções B também apresentaram um maior progresso de $3,6 \%$ para as populações com seleção entre e de 1,2\% para as po pulações com seleção entre e dentro e para as seleções AB obte ve-se um progresso de $16 \%$ para as populações com seleção entre e de 16,5\% com seleção entre e dentro. 
Não se detectou diferença significativa entre os tratamentos quando da aplicação dos testes F e Tukey'. Porém, para um melhor estudo dos dados, também foram desdobrados 11 graus de liberdade dos tratamentos (tabela 14), e como era de se esperar, todos os valores de F foram não significativos.

\subsubsection{Anālise conjunta}

Com os dados de produção obtidos nos dois : 10cais foi feita a análise conjunta da variância. De acordo com a análise, a média do experimento foi de $4,76 \mathrm{~kg} / 10 \mathrm{~m}^{2} \mathrm{com}$ um coeficiente de variação de 18,3\%. O teste $F$ para tratamentos e locais foi altamente significativo; o mesmo não ocorrendo com a interação tratamento por locais, que não apresentou significância dentro dos padrões convencionais de probabilidade (tabela 15).

A soma dos quadrados dos tratamentos foi desdobrada em: entre seleções $A$; entre seleções $B$; entre seleções $A B$; entre grupos; testemunhas e populações "versus" testemunhas (tabela 16). Para essas fontes de variação o teste F ape nas mostrou-se significativo a nível de 5\% de probabilidade na avaliação das seleções $A B$. Detectou-se diferença a nível de lo de probabilidade para a fonte de variação referente a populações "versus" testemunhas. 


\subsubsection{Progresso observado}

A partir dos dados médios de produção dos compostos ESALQ A e ESALQ B, nos estádios do processo seletivo, fo ram calculados os progressos observados. Estes progressos refletem o ganho obtido a cada passo do processo de seleção entre e dentro de familias de meios irmãos, aplicado aos compostos em questão. Convém lembrar que estes progressos descritos na tabela 17, revelam uma observação individual para cada popu lação e seus cruzamentos interpopulacionais. Trata-se de um progresso medido diretamente a partir das diferenças encontradas entre os dados médios de produção dos estádios originais e os estádios com seleção entre e seleção entre e dentro.

Os dados demonstram que os progressos foram mai ores com seleção entre do que com seleção entre e dentro de po pulações de meios irmãos, chegando esta ültima a apresentar dados semelhantes aos originais. Com relação aos cruzamentos interpopulacionais, detectou-se progresso no cruzamento de populações com seleção entre, o qual foi mantido no cruzamento de populações com seleção entre e dentro, o que é justificado pela crescente heterose denotada.

Para um estudo mais detalhado a respeito do pro gresso ocorrido entre os estádios de seleção do método seguida as fontes de variação: entre seleções $A$; entre seleções $B$ e en tre seleções AB, foram desdobradas em soma de quadrados linear 
e quadrático. Deste estudo, apresentado na tabela 18, obteve- se significância a nível de $5 \%$ apenas entre seleções $A B$ e entre grupos, sendo que o $F$ para seleções $A B$ está muito próximo do nível de probabilidade de $1 \%$.

A heterose do cruzamento das populações originais foi de $-0,17 \mathrm{~kg} / 10 \mathrm{~m}^{2}$, enquanto que a heterose entre as populações com seleção entre famílias de meios irmãos foi de $0,37 \mathrm{~kg} / 10 \mathrm{~m}^{2}$ e de $0,44 \mathrm{~kg} / 10 \mathrm{~m}^{2}$ entre as populações com seleção entre e dentro de famílias de meios irmãos.

Como medida complementar foi realizada uma anālise com base no processo de quadrados mínimos, onde foram cal culados os progressos médios e testadas as hipóteses de interesse. Através deste processo obtemos um progresso que resulta da avaliação das populações como um todo, levando, tambēm, em consideração o seu comportamento no cruzamento.

Os resultados da tabela 19 indicam que os desvios do modelo não foram significativos, mostrando que o modelo empregado foi adequado para explicar os resultados observados. Os progressos na população per se foram semelhantes aos métodos da análise anterior, não sendo significativos e não maztrando diferença significativa entre si. A heterose origi.... não se mostrou significativa, mas houve um progresso exA.....sisivo na heterose após um cíclo de seleção.

A figura 1 apresenta um gráfico com os valores 
dos progressos observados diretamente e dos progressos obtidos por regressão linear.

\subsection{Prolificidade}

A prolificidade é um dos componentes fundamentais na seleção para o aumento da produtividade de milho, apre sentando uma resposta correlacionada bastante significativa, a lém de ser um carater de fácil observação e seleção. Com sele ção para maior prolificidade os progressos na produção são alcançadøs em menor espaço de tempo.

\subsubsection{Anālise simples}

Nas tabelas 4 e 5 são apresentados os dados de prolificidade, obtidos em Āgua Santa e Anhumas, transformados em $\sqrt{\mathrm{x}}$ (SNEDECOR, 1946), sendo $\mathrm{x}$ o número de plantas da parcela, que apresentavam duas ou mais espigas. No ensaio de Água Santa as médias variaram de 6,9 a 11,8 plantas prolificas por parcela de 50 plantas; em Anhumas as médias variaram de 4,3 a 9,8 (considerando apenas as populações).

A anālise de variância destes dados estão nas tâ belas 12 e 13. Para Agua santa a média do experimento foi de 10,13 plantas prolificas/parcela de $10 \mathrm{~m}^{2}$, o que corresponde, em porcentagem aproximada de $20 \%$ de plantas prolificas; o coe- 
ficiente de variação foi de $16,8 \%$ e para os tratamentos o teste $F$ foi altamente significativo. Em Anhumas, a média do expẹ rimento foi de 7,54 plantas prolíficas/parcela de $10 \mathrm{~m}^{2}$, ou se ja $\pm 15 \%$ de plantas prolificas; o coeficiente de variação foi de $21,4 \%$, mais alto que Água Santa, o que mais uma vez pode ser explicado pela irrigação desuniforme. Para o teste F, os tratamentos foram altamente significativos.

Pelo teste Tukey não foram observadas diferenças significativas entre as médias das populações do ensaio de Água Santa, o mesmo não ocorreu no ensaio de Anhumas, onde as diferenças foram significativas a nível de 5 e $1 \%$ de probabili dade. Possivelmente, esta variação tambēm foi causada pela ir rigação não muito uniforme, que promoveu manchas no terreno, favorecendo o maior desenvolvimento em algumas plantas.

\subsubsection{Anālise conjunta}

Para os dados de prolificidade dos dois experimentos (tabela 15), foi realizada uma análise conjunta, a qual apresentou de acordo com $\circ$ teste $F$, dados altamente significatives para tratamentos, locais e para interação por locais. A média ficou em 8,79 plantas prolíficas/parcelas de $10 \mathrm{~m}^{2}$, com um coeficiente de variação de $18,9 \%$.

As diferenças entre as médias, nesta anālise, a 
presentaram significância a nível de 5 e 18, para o teste Tukey, o que é comprovado pela significância na interação tratamento por local. Os dados individuais mostram significância num experimento e não noutro, o que demonstra que a interação por local foi a responsável por esses resultados. No ensaio de Ågua Santa não se detectou diferença entre as médias das po pulações para prolificidade, porque, como já exposto anteriormente, este ambiente sofreu muito com a seca e possivelmente este fator tenha influenciado bastante na emissão da segunda espiga.

Com o objetivo de melhor exploração dos dados, desdobrou-se a soma dos quadrados dos tratamentos em: entre se leções $A$, entre seleções $B$, entre seleções $A B$, entre grupos, testemunhas e populações "versus" testemunhas (tabela 16). Pa ra estas fontes de variação o teste $F$, apenas não apresentou significância para os dados obtidos entre seleções A.

\subsubsection{Progresso observado}

Os progressos obsercados, referentes a prolificidade, são resultante da diferença entre os dados das populações originais e as populações com seleção entre e dentro. Na Zabela 17, os dados indicam que: a. entre seleções A registrou -se um progresso negativo ( -11 \& em relação ao original); b. en tre seleções B o progresso foi bastante expressivo para as po- 
pulações com seleção entre (32\% em relação ao original), já com seleção entre e dentro, denota-se um decréscimo $(14,7 \%$ em relação ao original); c. entre seleções $A B \circ$ progresso também foi mais acentuado nas populações com seleção entre $135 \%$ em re lação ao original), e houve um decréscimo na seleção entre e dentro ( $14 \%$ em relação ao original).

A soma dos quadrados das fontes de variação entre seleções $A$, entre seleções $B$, entre seleções $A B$ e entre grupos foram desdobradas em soma de quadrado linear e quadrátí ca (tabela 18). Os resultados apontam que: entre seleções A não existiu um progresso linear nem quadrático; entre seleções B O progresso é melhor explicado por uma equação quadrática; entre seleções $A B$ e entre grupos, tanto a resposta linear, como a quadrática descrevem o progresso obtido.

\subsection{Acamamento}

No decorrer do processo seletivo entre e dentro de famílias de meios irmãos, adotado neste trabalho, a caracte ristica acamamento foi devidamente anotada, eliminando-se as plantas acamadas de cäda parcela.

\subsubsection{Anälise simples}

Os dados de acamamento de Água Santa e Anhumas 
encontram-se na tabela 6 e 7, transformados em $\sqrt{x}$ e $\sqrt{x+0,5}$ respectivamente, sendo que $\circ \mathrm{x}$ corresponde ao nümero de plantas acamadas por parcela (SNEDECOR, 1946). Em Água Santa, a média variou de 14,7 a 9,7 plantas acamadas/parcela de $10 \mathrm{~m}^{2} \mathrm{e}$ em Anhumas de 5,6 a 12,0 plantas acamadas/parcela de $10 \mathrm{~m}^{2}$. Na análise da variância (tabela 12), para esses dados de Ãgua San ta, encontram-se 12,78 plantas acamadasy10 $\mathrm{m}^{2}$ como média do ex perimento, e coeficiente de variação de 14,8\%. Para 0 teste F, os tratamentos mostraram uma diferença significativa a nivel de 5\% de probabilidade. Para Anhumas (tabela 13), a média de experimento foi de 8,38 plantas acamadas $/ 10 \mathrm{~m}^{2}$ e o coeficiente de variação foi de $22,4 \%$. Segundo o teste $F$, os tratamen tos apresentam diferença significativa a nível de 5\%. Porém, através do teste de Tukey não foi auferida nenhuma diferença significativa entre as médias.

\subsubsection{Anāilise conjunta}

Da análise conjunta dos dados, obteve-se uma mê dia de 10,43 plantas acamadas/parcela de $10 \mathrm{~m}^{2}$ e coeficiente de variação de 18,3\% (tabela 15). Através do teste F detectou-se diferença significativa, a nível de 1\% de probabilidade, para tratamentos e locais, embora o mesmo não ocorreu para a intera ção tratamento por locais. 
Desdobrando-se os tratamentos (tabela 16), conforme já citado, obteve-se para o teste $F$, significancia a nivel de 1\% de probabilidade para as fontes de variação entre se leções $A$ e entre seleções $A B$.

\subsubsection{Progresso observado}

O progresso observado para resistência ao acama mento (tabela 17), nas populações selecionadas em relação às originais, mostrou-se efetivo nas populações A com seleção entre (-13\%), e nas populações AB com seleção entre e dentro (-17\%), observando-se ganhos mínimos nas populações B. Desdobrando-se a soma dos quadrados médios das populações em soma de quadrado linear e quadrática (tabela 18); conseguiu-se demonstrar que a resposta foi linear, apenas para as seleções $A B$, e quadrātica para seleções A, uma vez que as seleções B não apresentaram significância para resposta linear ou quadrática.

\subsection{Altura de plantas}

Num processo seletivo de milho para maior produ tividade, é muito importante que a característica altura de planta seja cuidadosamente observada, uma vez que, é fato reco nhecido na literatura a correlação positiva existente entre al 
tura de planta e produção. Sabe-se, portanto, que ao se elevar a produção, isto é acompanhado pela altura da planta, o que não é desejável, pois a medida que se aumenta a altura de planta, diminui-se a resistência ao acamamento, e a colheita mecânica é bastante prejudicada.

\subsubsection{Anālise simples}

Nas tabelas 8 e 9 são apresentados os dados mëdios de altura de planta, originadas de 10 observações por par cela, dos experimentos realizados em Água Santa.e Anhumas. Co mo pode se observar, no ensaio de Água santa as médias de altụ ra de planta variaram de 2,04 a 2,22 $\mathrm{m}$; em Anhumas as médias ficaram entre 2,18 a $2,36 \mathrm{~m}$.

As anālises de variância destes dados (tabelas 12 e 13) apresentaram, para Água Santa, média de experimento de 2,09 m e coeficiente de variação de 6,0\%; para Anhumas a média foi de 2,24 m e coeficiente de variação de 6,7\%. Para o teste $F$, os tratamentos foram significativos a $1 \%$.

Através do teste Tukey não foram detectadas diferenças significativas entre as médias das populações, nos dois ensaios. Observa-se que as populações no ensaio de Āgua Santa não diferiram das testemunhas em altura, o mesmo não se observando em Anhumas. 


\subsubsection{Anāi ise conjunta}

Com a anālise conjunta dos dados (tabela 15), de altura de planta dos dois ensaios (Tabela 15) obteve-se uma média de 2,17 m e coeficiente de variação de 6,4\%. Da análise, ainda depreende-se que os tratamentos e os locais apresentaram diferenças significativas a nível de 1\% de probabilidade, porém, não se observou diferença significativa na interação tratamento por local.

Num estudo detalhado, os graus de liberdade dos tratamentos foram desdobrados da seguinte maneira: entre seleções $A$; entre seleções $B$; entre seleções $A B$ e entre grupos. Nes ta avaliação, notou-se significância entre grupos e entre popu lações "versus" testemunhas para o teste $F$ a nivel de 5 e 18 , respectivamente (tabela 16).

\subsubsection{Progresso observado}

Na tabela 17 encontram-se os dados referentes ao progresso obtido a partir das populações originais. Os dados indicam que, basicamente, não houve variação entre as popu lações originais, com seleção entre e com seleção entre e dentro, não se detectanto nenhum progresso positivo ou negativo pa ra este caracter. 
Para uma confirmação do exposto acima, a soma de quadrado dos dados médios foi desdobrada em soma de quadrado linear e quadrática, não se observando nenhuma significância para as respostas liner ou quadrática (tabela 18).

\subsection{A.ttura de espiga}

De maneira semelhante, a altura da espiga está diretamente correlacionada com a produção, de forma que, se se lecionando para maior produção, deve-se tomar cuidado para não se elevar a altura da espiga.

\subsubsection{Anālise simples}

Os dados de altura de espiga dos dois experimen tos encontram-se nas tabelas 10 e 11 . Verifica-se que os dados médios para tratamento variaram de 1,16 a 1,19 m em Ãgua Santa, e de 1,28 a 1,40 m em Anhumas, considerando-se apenas as populações. De maneira semelhante aos dados de altura de planta, os dados de altura de espiga foram mais elevados no ensaio de Anhumas.

Fazendo-se a anālise de variância para estes dạ dos, obteve-se para Ãgua Santa a média de 1,22 m, e coeficiente de variação de 8,0\% (tabela 12); para Anhumas a média de ex 
perimento foi de $1,34 \mathrm{~m}$ e coeficiente de variação de $8,7 \%$ (tabela 13). Para o teste $F$, os tratamentos foram significativos a nível de 1\% de probabilidade, apenas para o ensaio realizado em Ãgua Santa.

Aplicando-se o teste Tukey, para os dados mëdios de Ågua Santa, não se observou diferenças significativas.

\subsubsection{Anālise conjunta}

De acordo com a análise conjunta dos dados dos dois ensaios (tabela 15), obteve-se a média de 1,28 m e coeficiente de variação de $8,4 \%$. Para o teste F, observou-se signi ficância a nível de $1 \%$ de probabilidade para os tratamentos e locais, não se observando significância para a interação tratą mento por local.

Dando sequência, de modo semelhante às características estudadas anteriormente, a soma de quadrado dos tratą mentos foram desdobrados. Deste estudo apenas detectou-se sig nificância a nível de l\% entre grupos e para populações "versus" testemunhas (tabela 16).

5.5.3. Progresso observado

Os dados de progresso observado para altura de 
espiga estão na tabela 17. Para as seleções A, observou-se um progresso na diminuição de altura da planta, de 3,0\%. Na sele מิo B houve um progresso de 4,1\% para seleções entre, porēm, úpenas 1,6\% na seleção entre e dentro (em relação a população original). Para os cruzamentos interpopulacionais, nada se ob servou nas populações com seleção entre, porém com seleção entre e dentro o progresso foi de $2,3 \%$ em relação ao original.

Desdobrando-se as somas de quadrados médios dos tratamentos em linear e quadrático, não foi possivel determinar nenhuma resposta para o progresso obtido, visto ser este muito pequeno (tabela 18). 
6. DISCUSSAOO

6.1. Seleção entre e dentro de famîlias de meios irmãos para produção

O melhoramento de populações é de primordial im portância como ferramenta complementar na obtenção de linhagens para produção de hỉbridos, uma vez que, através do melhoramento de populações eleva-se a frequência dos genes favorāveis, aumentando as probabilidades de se obter maior número de linhagens elites, além de se tratar de uma maneira melhor dire cionada para tal; evitando-se a aleatoriedade na obtenção de linhagens, do método tradicional de obtenção de híbridos. o mê todo de melhoramento de populações estudado foi o de seleção entre e dentro de familias de meios irmãos; método este existente hā muito tempo, mas que só se tornou eficiente a partir de uma série de modificações propostas por LONNQUIST (1964). 
O método de seleção entre e dentro de famílias de meios irmãos com sementes remanescentes, promove um ciclo de seleção a cada dois anos, visto que a recombinação é feita no ano seguinte, junto com a seleção dentro de famílias, com a vantagem de que as linhas polinizadoras correspondem a uma mis tura equitativa das sementes das melhores progênies selecionadas. Portanto, a variância aditiva a ser explorada é bem maior do que quando se usa o mesmo método sem sementes remanescentes, porêm este promove um ciclo de seleção por ano, diminuindo as sim o efeito da interação, pois o material é selecionado todo ano.

Os trabalhos de experimentação com milho no Bra sil, empregando-se anālise em látice ou em blocos ao acaso, apresentam coeficiente de variação na amplitude de 10 a $20 \%$, que é considerado uma precisão satisfatória pelos seguintes au tores: PATERNIANI (1967, 1968a), QUEIROZ (1969) e MOTA (1974). Neste trabalho, para produção obteve-se coeficiente de variação de 17,3\% e 19,5\% em Água santa e Anhumas; na análise conjunta o coeficiente de variação foi 18,3\%.

Estudando-se com detalhe os estádios do método de seleção entre e dentro de famílias de meios irmãos, com sementes remanescentes, obteve-se para as populações do composto ESALl A com seleção entre e com seleção entre e dentro, em relação à população original, um progresso de 4,6 e 0,2\%, respec tivamente. Para o composto ESALQ B com seleção entre e com se 
leção entre e dentro, os progressos foram de 3,6 e 1,28, respectivamente. Como pode se observar, os ganhos obtidos nas ge. rações de um ciclo, não corresponderam a uma reta ascendente. Provavelmente, estudando-se outros estádios deste método em cí clos subsequentes, encontrar-se-á oscilações nos progressos ob tidos, indicando variações erráticas. Isto normalmente ocorre quando se estuda um ṇúmero restrito de gerações.

FALCONER (1960), estudando essas variações erráticas, apresenta como cau sas principais das variações das médias a variação de amostragem e mudanças no ambiente, sendo a ültima a mais importante. O autor considera a linha de regressão ajustada para as médias das gerações como a melhor maneira de se avaliar, com precisão as tendèncias dessas médias. De posse dessa informação, neste trabalho pode-se também, basear as discussões nas curvas de re gressão para produção, assinaladas na figura l. Porém, convēm lembrar que este estudo objetivou apenas detalhar os efeitos das seleções entre e dentro, que fazem parte do método em ques tão, e que para se ter uma idéia da tendência da curva de progresso, são necessários vários ciclos de seleção.

De acordo com os resultados obtidos, pode se de preender que o progresso demonstrou ser mais eficiente quando se efetuou a seleção entre famílias de meios irmãos; tal resul tado já era previsto por CRISŌsTomo (1978) quando, estudando os parâmetros genéticos das mesmas populações, avaliou a herda bilidade. 
o material que sofreu seleção massal dentro das familias é resultado do diferencial de seleção obtido por CRISÓSTOMO (1978) e da avaliação com testemunha intercalar (SOUZA JUNI@R et alii, 1978). Este material não se mostrou mais produtivo com seleção dentro, possivelmente, devido a interação por anos, que deve ter influenciado negativamente os valores obtidos, ou mesmo no ano anterior, os resultados todos foram superiores pạa seleção entre, por se tratar de um ano favorāvel. Em outras palavras, sendo o método de seleção com sementes remanescentes, as seleções são feitas em anos diferentes, o que possibilita haver interações dos genótipos por anos e conduzindo a dados sub e superestimados.

Resultados semelhantes aos do presente estudo foram encontrados por LIMA (1977), que empregando seleção entre e dentro de famílias de meios irmãos com sementes remanescentes no melhoramento da população ESALQ-VD-2, obteve progres so genético na seleção entre famillias duas vezes superior ao com seleção dentro de famílias.

Portanto, seleção entre e dentro de famílias de meios irmãos com sementes remanescentes, permite que se traba Ihe com maior variância genética aditiva, porém, sua exploração é bastante prejudicada pela interação genótipo por ano. RAMALHO (1977), concorda que a seleção entre e dentro de famílias de meios irmãos sem sementes remanescentes (l ciclo por ano) proporcione ganhos anuais maiores do que com uso de semen 
tes remanescentes ( 1 ciclo cada 2 anos); afirmando ainda que esta vantagem è tanto maior quanto maior for a intensidade de seleção entre famílias e maior for a magnitude da variância aditiva, o que está de pleno acordo com os resultados obtidos neste trabalho, onde se aplicou grande intensidade de seleção entre familias, em material de grande variabilidade. Esta intensidade de seleção é justificada por PATERNIANI (1968a), que admite que se utilizando um nümero maior de progênies (superios a 300), pode-se aplicar uma alta intensidade de seleção entre as progênies, sem que a variabilidade da população seja muito afetada.

Outro ponto de apoio para dar continuidade a es ta discussão tambēm encontra-se em PATERNIANI (1968a), que afirma que o progresso obtido por qualquer método depende da vâ riabilidade genética presente no material, e que a variabilida de genética dentro de progênies de meios irmãos e as interações genōtipo por ambiente contribuem para aumentar o coeficiente de variação, com isso tem-se, possivelmente, os presen tes dadaos médios influenciados pelo componente ambiental, prejudicando em parte a seleção feita dentro das progênies de i. ios irmãos.

Seguindo a mesma metodologia usada no presente tr.balho, SUAREZ LEZCANO (1976), CUNHA (1976), WINKLER (1977) e IIMA (1977) obtiveram ganhos com a seleção entre e dentro de famílias de meios irmãos, após um ciclo de seleção, da ordem 
de $7,4 \%, 5,3 \%, 6,2 \%$ e $10,8 \%$, respectivamente. Dados bastante superiores aos encontrados no presente estudo, porém deve-se ressaltar que são resultados da média dos ganhos por ciclo, e não referentes a um único ciclo, como no presente caso.

ZINSLY (1969), trabalhando com as populações Dente Paulista, Caingang e Cateto, aplicando o método de seleção entre e dentro de famílias de meios irmãos sem sementes re manescentes, encontrou resultados expressivos. PEIXOTO e ZIN LY (1979), fazendo uma comparação entre os progressos obtidos na seleção entre e na seleção dentro das progênies destás popu lações, observaram que os mesmos foram semelhantes e estão de acordo com os obtidos por WEBEL e LONNQUIST (1967), PATERNIANI (1968a), SILVA (1969), CARMO (1969) e TORRES SEGOVIA (1976).Pa ra todos esses casos, as comparações devido a seleção entre fa mílias e dentro de famílias foram feitas quando um ciclo era completado em um ano. Era de se esperar que o resultado do presente estudo diferisse, pois se trata de um ciclo: a cada dois anos, e de acordo com a literatura, o ganho devido a sele ção entre é superior 1,5 a 2 vezes quando se utiliza sementes remanescentes.

$\mathrm{Na}$ literatura encontra-se, para maioria dos tra balhos de melhoramento, que o maior decréscimo de variabilidade genética tem sido registrado da população original para o primeiro ciclo (PATERNIANI, 1967, 1968a; WEBEL e LONNQUIST, 1967; POMMER et alii, 1977). A semelhança destes dados, fazen 
do-se o estudo do método proposto, observou-se um maior progresso no primeiro estádio de seleção entre famílias, onde a variabilidade genética disponível era maior do que no estádio de seleção dentro de famílias.

AJUDARTE NETO (1979), aplicando seleção dentro de famílias de meios irmãos em couve-brócolos, afirma que o em prego somente dentro de progênies foi eficiente, promovendo progressos satisfatórios na produção. Os resultados do presen te trabalho discordam desta consideração, porém ressalta-se que são consequência de observações de um único ciclo de seleção, onde a interação talvez possa ter mascarado os resultados. No entanto, estes resultados estão de conformidade com COMPTON e COMSTOCK (1976), que admitiram que o método de seleção entre e dentro de famílias de meios irmãos com sementes remanescentes é cerca de $25 \%$ menos eficiente quando comparado aqueles obtidos com uma geração por ciclo e justifica-se o seu uso por ser de fácil manejo e pouco dispendioso.

Nos cruzamentos interpopulacionais realizados neste trabalho, entre as populações originais, com seleção entre e com seleção entre e dentro, observou-se que as produções foram bastante elevadas, e apresentaram diferença significatita a nível de 5\% de probabilidade. Os progressos, em relação a população original, foram de 16,0\% para seleção entre famílias, e de 16,5\% para seleções entre e dentro de familias, apresentando uma resposta linear para o progresso. Estes resul 
tados demonstraram o efeito heterótico do cruzamento, o que es tá de acordo com VALOIS (1973), que afirma que a seleção intra populacional tende a refletir na média do cruzamento ou híbrido de populações; o autor assinada ainda que a produção. de grãos de híbridos de variedades pode ser superior ao híbrido das respectivas variedades originais.

De acordo com os dados obtidos para heterose, depreende-se que ela foi crescente a medida que se processou a seleção entre e dentro das famílias de meios irmãos dos compos tos, apesar de não se ter observado um aumento crescente na produção da população per se.

Portanto, o sucesso da seleção é devido a aumen tos nas médias das populações per se e a modificações na heterose do cruzamento das mesmas. Consideração semelhante foi feita por PATERNIANI (1969), onde a heterose aumentou com a se leção e resultou no bom cruzamento entre Dente Paulista III e Piramex III; já nos experimentos de LONNQUIST (1961) e MOLL e ROBINSON (1967) a heterose permaneceu constante. A heterose pode, porēm, diminuir a medida que reduz a diversidade genētica existente entre as populações, de acordo com PATERNIANI (1961), MOLL et alii (1965).

PEREIRA (1976), em quatro ciclos de seleção entre e dentro de familias de meios irmãos e quatro ciclos de se leção massal estratificada, não observou alteração na produti- 
vidade da população. De maneira semelhante, nos resultados deste trabalho não se observou progressos expressivos na média das populações per se, não se alterando a frequência genica mé dia, no entanto, criou-se grande diversidade entre elas, o que foi realçado pelos cruzamentos interpopulaçionais.

6.2. Seleção entre e dentro de famîlias de meios irmãos para caracteres correlacionados com a produção

O estudo dos caracteres correlacionados com a produção é de suma importância para o melhoramento, pois em ge ral os melhoristas se preocupam em aprimorar o material não pá ra caracteres isolados, mas para um conjunto de caracteres simultaneamente. E fundamental, que se atenda aos caracteres a gronômicos desejados, para se obter um material que esteja melhor adaptado às condições de clima, praga, patógeno, e mesmo, para melhor aceitação das técnicas modernas de plantio, colhei ta e processamento. Pensando-se nessas proposições considerou -se conveniente, para um estudo do método de seleção entre e dentro de famílias de meios irmãos, com sementes remanescentes, que fossem anotadas determinadas características correlacionadas positiva ou negativamente com a produção, e, de maneira se melhante ao carater produção, estudar os progressos obtidos e as curvas de regressão de cada característica. 
CAMPOS (1966) concorda com as proposições acima, e afirma que a seleção não deve ser feita, unicamente, com base num só carater, uma vez que, o aumento do peso total de grãos é devido a pequenas variações em muitos caracteres,e não grandes variações em apenas um. De maneira semelhante VENCOVSKY (1978) concorda com o fato de que as características correlacionadas devem ser aprimoradas simultaneamente. AJUDARTE NETO (1979), admite que a seleção visual, baseada em um Indice seletivo primário, o valor global da planta, alterou de maneira positiva a produção das populações de couve-brocolos estudą das.

Na literatura é fato bastante conhecido a corre lação positiva existente entre altura de planta e espiga com a produção, sendo discutivel a possibilidade de se aumentar a produção sem alterar o porte da planta. Por serem estes carac teres bastante estudados, a base genética destes jā é definida no que diz respeito ao tipo de herdabilidade e ao tipo de predominância gênica. De acordo com ROBINSON et alii (1949) e QUEIROZ (1969), altura de planta e espiga apresentam herdabili dade relativamente alta.

De maneira semelhante a prolificidade, tambēm está positivamente correlacionado com a produção (BAUMAN, 1960; GOODMAN, 1965; CAMPOS, 1966; LONNQUIST et alii,1966; VIL LANO, 1966; LIABLE e DIRKS, 1968; QUEIROZ, 1969 e POMMER, 1977). Inclusive LONNQUIST (1967) demonstrou que a seleção para prolí 
ficidade foi mais eficiente na seleção para produtividade que a seleção para produção per se.

Para o carater acamamento não foi observada cor relação para produção nos trabalhos de JUGENHEINER (1958) entre linhagens, de CAMPOS (1966), dentro de uma variedade, e de ELROUBY e PENY (1967) em progênies biparentais de variedades . No entanto, CAMPOS (1966) obteve correlação negativa e signifi cativa entre acamamento e produção em uma variedade e hibridos.

Os dados do presente estudo mostram que, para as populações do composto ESALQ A (tabela 17), à medida que a altura da planta e espiga điminuem, a prolificidade também diminui; este fato somado ao indice de acamamento provocaram queda sensivel na produção. Nos testes estatísticos não se detectou diferença significativa para produção, bem como para as características positivamente a ela correlacionadas; embora, tenha se detectado uma diferença significativa, a nível de $1 \%$ de pro babilidade, para o Indice de acamamento. No caso das populações com seleção entre, alguns resultados são discordantes da literatura, como o aumento do Indice de acamamento, acompanhaio de menor Indice de prolificidade, menor altura de planta e spiga e sensível elevação na produção. Na população com sele ção entre e dentro, os resultados são mais consonantes com a literatura, ou seja, com as características correlacionadas; o decréscimo da produção foi acompanhado de um menor índice de 
prolificidade e menor altura de planta e espiga, não havendo um acréscimo no Indice de acamamento.

Nas populações do composto ESALQ B (tabela 17), os dados obtidos estão de conformidade com a literatura. $\bar{\AA}$ me dida que se elevou a altura da planta e da espiga e a prolificidade, a produção também se elevou. Observa-se que o indice de acamamento acompanha a prolificidade, ou seja, quando se eleva a prolificidade, o acamamento também se eleva. Provavelmente isto ocorre devido ao fato das plantas prolíficas tornaram-se mais altas e mais pesadas, acamando com mais facilidade.

Estudando-se a população do composto ESALQ B , com seleção entre, verifica-se que o avanço na produção é acom panhado positivamente pelos caracteres altura de planta e espi ga, prolificidade e menor acamamento. Na população com seleção entre e dentro nota-se que a produção sofreu um decréscimo junto com a altura de espiga, prolificidade e um maior acamamen to.

Nas populações $A B$ não se observou grandes varia ções na altura da planta e espiga, porém notou-se um aumento na produção acompanhada de um menor acamamento, apesar da queda de prolificidade. Analisando-se por etapas percebe-se que as populações $A B$ com seleção entre não apresentam variações na altura de planta e espiga, porém elevou-se a prolificidade, di minuindo-se o indice de acamamento e aumentou a produção em 
16\%. Na seleção dentro nota-se que baixou a altura de planta a espiga, diminuiu a prolificidade e acamamento, apesar de um acréscimo na produção de $0,5 \%$ em relação à população com sele ção entre.

E, portanto, bastante difícil para o melhorista julgar dentro de uma análise global das características, que rumo tomar para ter sucesso. Porém, é muito importante que num programa de melhoramento se leve em conta todos os caracte res agronômicos correlacionados. Com base nestas considerações, pode-se também dizer que o motivo de muitos dados observados neste trabalho não estarem de acordo com a literatura, se ja porque, na seleção se levou em conta os caracteres agronômi cos de uma maneira global. ZINSLY (1969) e PEIXOTO e ZINSLY (1979), obtiveram progressos semelhantes para seleção entre e para seleção dentro, considerando apenas o carater produção, independente das plantas mais produtivas estarem acamadas, apresentarem elevada altura de planta e espiga ou de serem prolificas.

Apesar da correlação positiva entre produção e altura de planta e espiga ser um fato bastante discutido na li teratura, neste estudo levanta-se a possibilidade desta planta mais alta ser mais produtiva pelo fato de ser menos sombreada, e competir positivamente pela luz. Se fosse possivel plantarse separadas as plantas altas das baixas, estas últimas não seriam sombreadas pelas altas, e talvez, as produções seriam 
semelhantes.

De acordo com os dados do presente trabalho não se verificou diferenças significativas entre as características altura de planta e espiga, de um estádio para outro de seleção entre e dentro de famílias de meios irmãos, com sementes remanescentes. Isto pode ser considerado como um fato positivo, pois processou-se a seleção para produção sem aumentar a sua altura, principalmente na etapa referente à seleção entre familias, onde se obteve um certo progresso na produção.

Considerando que a seleção entre famílias é feî ta através de ensaios com repetições, é de se esperar que ela dê resultados mais satisfatórios do que a seleção dentro de fa mílias, a qual é realizada em uma única repetição, e nesta leva-se em conta o valor global da planta, ou seja, altura da planta e espiga, prolificidade e acamamento. Fazendo-se um pa rênteses, poderiam ser discutidas as vantagens de uma em relação à outra, ou mesmo qual das etapas atendem melhor aos objetivos do método proposto. Desta forma, pode-se dizer que a se leção entre famílias é bem mais trabalhosa e dispendiosa, uma vez que exige grande ārea para se colocar as repetições; já a seleção dentro de famílias é bastante simples, pois è feita nu ma só repetição. Com respeito aos efeitos que cada uma delas promove, cria-se um impasse, pois uma promove uma avaliação mais precisa, quando a variabilidade genētica é bastante ampla, enquanto que a outra permite que se faça avaliações com base nos fenōtipos desejados. 
7. CONCLUSJ̈ES

De acordo com o estudo do método de seleção entre e dentro de famílias de meios irmãos, desenvolvido no presente trabalho, foi possivel tirar as seguintes conclusões:

- Obteve-se um maior progresso entre progènies, devido a maior variabilidade genética disponível do material , e também pelo fato de que a seleção dentro de famílias foi fei ta visando todos caracteres agronômicos desejāveis, além da produção.

- Nos cruzamentos interpopulacionais, observou-se um progresso crescente com seleção entre e dentro de famílias de meios irmãos. Embora o processo seletivo não tenha si do eficiente em todos os estádios para aumentar a média per se das populações, este foi eficiente para promover a divergència genética entre elas, sendo esta evidenciada pela heterose cres 
.67 .

cente.

- Os resultados observados não coincidiram amplamente com os esperados teoricamente.

- Durante o processo seletivo nao se observou diferenças significativas entre as caracteristicas altura de planta e espiga de um estádio para o outro. 
8. SUMMARY

The breeding of maize populations is of

fundamental importance in the preliminary process of a hybrid program. There are several methods of population selection, each one with its own characteristics. This research deals with a detailed study of the method of selection among and within half sib families with remaining seeds.

The material used for this evaluation were the composites ESALQ A and ESAIQ B, in the original stages, with selection among and selection among and within; as well as the crossing of these composites in these stages, in order to evaluate the heterosis during the selective process.

The agricultural characteristics evaluated were: production, prolificity, lodging, plant and ear height, with higher emphasis in production. Such observations were 
made at each stage of the selective process, in an experiment of randomized stocks with nine replications.

Acording to the data obtained one can see a greaten progress in the production when selection among families was made in 1977 than within families in 1978. This can be explained by the fact that the selection among families is made through replicated experiments thus providing more realistic data; on the other hand, being a method which uses remaining seeds, the selection among is made in one year and the selection within in another, so that interaction by years may promote understimated or overestimated data.

In the interpopulation crossings an increasing progress of the original populations to those with selection among and within was observed. Therefore the selective process of populations contributed to a greater divergence among populations which is enhanced by the heterosis.

During the cycle of selection among and within half sib families significant diferences between plant and ear height from one stage to the other were not observed. One can consider this as a positive fact once the selection for production was processed without increasing plant and ear height, mainly in the stage concerned to selection among families, where a certain progress in the production was obtained. 
9. LITERATURA CITADA

BAUMAN, L.F., 1960. Relative yields of first (apical) and second ears of semi-prolific southern corn hybrids. Agron. J. Madison, 52:220-222.

BEAL, W.J., 1877. Report of the Professor of Botany ana Horticulture. Rept. Mich. Bd.Agr. pp. 41-59. Apud SPRAGUE, G. F., 1955. Corn Breeding: In: Corn and Corn Improvement. New York, Academic Press. 699 p.

CAMPOS, M.S., 1966. Efeitos da seleção entre e dentro de progênies de meios irmãos em duas populações de milho. Piraci. caba, ESALQ/USP. 42 p. (Tese de Mestrado).

CARMO, C.M., 1969. Avaliação de progênies de meios irmãos em população heterogenaa de milho (zea mays L.). Piracicaba, ESALQ/USP, $48 \mathrm{p}$. 
COLLIER, J.W., 1959. Three cycles of reciprocal recurrent selection. Proc. 14th Annual Hybrid Corn Industry Research Conference. American seed Trade Association Pub. $\underline{14}: 12-23$

COMPTON, W.A. e K. BAHADUR, 1977. Ten cycles of progress from modified ear-to-row selection in corn. Crop Sci. Madison, $17: 378-380$.

COMPTON, W.A. e R.E. COMSTOCK, 1976. More on modified ear-torow selection in corn. Crop Sci. Madison, 16:122.

COMSTOCK, R.E., H.F. ROBINSON e P.H. HARNOY, 1949. A breeding procedure designed to make maximum use of both general and specific combining ability. Agron. J. Madison, 4l:360-367.

CRISŌSTOMO, J.R., 1978. Estimação de parâmetros genēticos visando seleção em dois compostos de milho (Zea mays L.). Pi racicaba, ESALQ/USP, 71 p. (Dissertação de Mestrado).

CUNHA, M.A.P. da, 1976. Seleção entre e dentro de famílias de meios irmãos no milho (Zea mays L.) ESALQ-HV-I. Piracicaba, ESALQ/USP, $84 \mathrm{p}$. (Tese de Doutoramento)

DOUGLAS, A.G. , J.W. COLLIER, M.F. EL-EBRASHY e J.S. ROGERS, 1961. An Evaluation of three cycles of reciprocal recurrent selection in a corn improvement program. Crop Sci. 1:157161. 
EAST, E.M., 1908. Inbreeding in corn. Connecticut Agr. Expt. Sta. Rept. 1907; p. 419-428.

EBERHART, S.A., M.N. HARRISON e F. OGADA, 1967. A comprehensive breeding system. Der Züchter. New York, 37:169-134.

ELROUBY, M.M. e L.H. PENNY, 1967. Variation and covariation in high oil population of corn (Zea mays L.) and their implications in selection. Crop Sei. Madison, 7:216-219.

FALCONER, D.S., 1976. Introduction to quantitative genetics. 6a. imp. London, Logman. $365 \mathrm{p}$.

GARDNER, C.O., 1961. An evaluation of effects of mass selection and seed irradiation with thermal neutrons on yield of corn. Crop. Sci. Madison, $\underline{1}: 241-245$.

GARDNER, C.O., 1973. Evaluation of mass selection and of seed irradiation with mass selection for population improvement. in maize. Genetics. Austin, 74:588-589.

GOODMAN, M.M., 1965. Estimates of genetic variance in adapted and exotic populations of maize. Crop Sci. Madison, 5:87-90 .

GARDNER, C.O. e S.A. EBERHART, 1966. Analysis and interpretation of the variety cross diallel and related populations. Biometrics. 22: 439-452. 
GRIFFING, B., 1956a. A generalized treatment of the use of diallel crosses in quantitative inheritance. Heredity. $10: 31-50$

GRIFFING, B., 1956b. Concept of general and specific combining ability in relation to diallel crossing systems. Australian Jour. Biol. Sci. 9 :463-493.

HOPKINS, C.G., 1899. Improvement in the chemical composition of the corn kernel. Ilzinois Agr. Expt. Sta. Bull. Illinois, 55:205-240. Apud: SPRAGUE, G.F., 1955. Corn Breeding. In: Corn and corn improvement. New York. Academic Press. 699 p.

JONES, D.F., 1918. The effects of inbreeding and cross breeding upon development. Connecticut Agr. Expt. Sta. BuZ2. 207:1-100.

JUGENHEIMER, R.W., 1958. Hybrid maize breeding and seed production. In: Food and agriculture organization of the United Nations. Rome, p. 100-103.

LIABLE, C.A. e V.A. DIRKS, 1968. Genetic variance and selective value of ear number in corn (zea mays L.). Crop Sci. Madison, 8: 540-543.

LIMA, M., 1977. Seleção entre e dentro de famílias de meios irmãos na população de milho (Z ea mays L.) ESALQ-VD-2. Piracicaba, ESALQ/USP. 71 p. (Dissertação de Mestrado). 
LONNQUIST, J.H., 1960. El mejoramiento de las poblaciones de mays. P.C.C.M.M. Managua, $\underline{6}: 14-22$.

LONNQUIST, J.H., 1961. Progress from recurrent selection procedures for the improvement of corn populations. Nebras ca. Agric. Expt. Sta. Res. Buzz. 197. 33 p.

LONNQUIST, J.H., 1964. A modification of the ear-to-row procedure for the improvement of maize populations. Crop Sci. Madison, $\underline{4}: 227-228$.

LONNQUIST, J.H., 1967a. Mass selection for prolificacy in maize. Der Eüchter. Berlin, 37:185-188.

LONNQUIST, J.H., O.A. COTA e C.O. GARDNER, 1966. Effect of mass selection and thermal neutrons irradiation on genetic variances in a variety of corn (zea mays L.). Crop. Sci. Madison, $6: 330-332$.

MOLL, R.H. e H.F. ROBINSON, 1966. Observed and expected response in four selection experiments in maize. Crop Sci. $\underline{6}: 319-324$.

MOLL, R.H. e H.F. ROBINSON, 1967. Quantitative genetic investigations of yield of maize. Der Züchter. 37:191-199.

MOLL, R.H., W.S. SALHUANA e H.F. ROBINSON, 1962. Heterosis and genetic diversity in variety crosses of maize. Crop Sci. 2: $197-198$. 
MOEL, R.H., J.H. LONNQUIST, J. VELEZ FORTUNO E E.C. JOHNSON, 1965. The relationship of heterosis and genetic divergence in maize. Genetics. Austin. 52:139-144.

MORO, J.R., J.R. ZINSLY e E. PATERNIANI, 1974. Seleção recorrente recíproca em famílias de irmãos germanos de milho (Zea mays L.). Rez. Cient. Inst. Genética. ESALQ/USP. Pí. racicaba, 8 : $139-147$.

MOTA, M.G., 1974. Comportamento de progênies de meios irmãos e $S_{1}$ na variẹdade de milho (Zea mays L.) Centralmex. Piracicaba, ESALQ/USP. 52 p. (Disserkação de Mestrado).

PATERNIANI, E., 1961. Cruzamentos interraciais de milho. Piracicaba, ESALQ/USP. 46 p. (Tese de Livre-Docência).

PATERNIANI, E., 1967. Selection among and within half sib families in brazilian population of maize (Zea mays L.). Crop Sci. Madison, 7:212-216.

PATRRNIANI, E., 1968a. Avaliação do método de seleção entre e dentro de familias de meios irmãos no melhoramento de milho (Zea mays L.). Piracicaba, ESALQ/USP. 92 p. (Tese de Pro fessor Catedrātico).

PATERNIANI, E., 1968b. Formação de compostos de milho. Rez. Cient. Inst. Genética. ESALQ/USP, Piracicaba, 2:102-107.

PATERNIANI, E., 1969. Melhoramento de populações de milho. Cí ência e Cultura. São Paulo, 21:1-10. 
PATERNIANI, E., 1971. Seleção recorrente recíproca com plantas prolificas. Rel. Cient. Inst. Genëtica. ESALQ/USP, Pi racicaba, $\underline{5}: 129-132$.

PEIXOTO; T.C. e J.R. ZINSLY, 1979. Estudo da seleção entre e dentro de familias de meios irmãos em populações de milho (Zea mays L.). Ecossistema. Espirito Santo do Pinhal, 4: $63-66$.

PEREIRA, P., R. MAGNAVACA, M.A. LEMOS, J.F.F. de TOLEDO e A.E. da SILVA, 1976. Seleção entre e dentro de famílias de meios-irmãos, no milho (Zea mays L.) Cateto Columbia Compos to. Anais da XI Reunião Brasileira de Milho e Sorgo. Pira cicaba, 175-183 p.

PIMENTEL GOMES, F., 1976. Curso de Estatistica Experimental . 6a. ed. São Paulo. Livraria Nobel, 430 p.

POMMER, C.V., L.T. de MIRANDA, L.E.C. de MIRANDA e E. SAWAZAKI, 1977. Estimativas de parâmetros genēticos na população de milho IAC-1 opaco-2. Bragantia. Campinas, 36:197-205.

QUEIROZ, M.A., 1969. Correlações genēticas e fenotípicas em progênies de meios irmãos de milho (Zea mays L.) e suas implicações no melhoramento. Piracicaba, ESALQ/USP. 71 p. (Tese de Mestrado). 
RAMALHO, M.A.P., 1977. Eficiência relativa de alguns processos de seleção intra populacional no milho baseado em famílias não endógamas. ESALQ/USP. 122 p. (Tese de Doutoramento).

RICKEY, F.D., 1922. The experimental basis for the present status of corn breeding. J.Am. Soc. Agron. Madison, 14: $1-17$.

ROBINSON, H.F., R.E. COMSTOCK e P.H. HARVEY, 1949. Estimatives of heritability and the degree of dominance in corn. Agron. J. Madison, 41:353-359.

ROBINSON, H.F., R.E. COMSTOCK e P.H. HARVEY, 1955. Genetic variances in open-pollinated varieties of corn. Genetics. Austin, 40: $45-60$.

SHULL, G.H., 1909. A pure line method of corn breeding. Amer. Breed. Assoc. Rep. $\underline{5}: 51-59$.

SILVA, J., 1969. Seleção entre e dentro de familias de meios irmãos no milho Cateto Colombia Composto. Piracicaba,ESALQ/ USP. 74 p. (Tese de Mestrado).

SMITH, L.H. e A.M. BRUNSON, 1925. An experiment in selecting corn for yield by method of the ear-to-row breeding plot. Agr. Expt. Sta. Buzl. Illinois, 271:567-583. Apud: SPRAGUE, G.F., 1955. Corn Breeding. In: Corn and corn improvement. New York, Academic Press. 699 p. 
.78 .

SNEDECOR, G.W., 1946. Statistical methods applied to experiments in agriculture and biology. Iowa state college Press. 4a. ed. 557p.

SOUZA JUNIOR, C.L., T.C. PEIXOTO, R. VENCOVSKY E J.R. ZINSLY; 1978. Considerações a respeito do nümero de repetições utí zado na avaliação de progênies. Rel. Cient. Inst. Genética. ESALQ/USP. Piracicaba, 12:185-193.

SPRAGUE, G.F., 1955. Corn breeding. In: Corn and corn improvement. New York. Academic Press. 699 p.

SPRAGUE, G.F., 1971. Genetic vulnerability to disease and insects in corn and sorghum. Ann. Corn. and Sorghum Res. Conf. Proc., 26:96-104.

SPRAGUE, G.F. e L.A. TATUM, 1942. General vs. specific combining ability in single crosses of corn. J.Am. Soc. Agron. 34:923-932.

SUÅREZ LEZCANO, R., 1976. Seleção entre e dentro de famílias de meios irmãos no milho (Zea mays L.) Composto Flint Branco. Piracicaba, ESALQ/USP. 52 p. (Dissertação de Mestrado) .

TORRES SEGOVIA, R., 1976. Seis ciclos de seleção entre e dentro de familias de meios irmãos no milho (Zea mays L.) Centralmex. Piracicaba, ESALQ/USP. 98 p. (Tese de Doutoramento) . 
VALOIS, A.C.C., 1973. Efeito da seleção massal estratificada em duas populações de milho (Zea mays L.) e na heterose dos seus cruzamentos. Piracicaba, ESALQ/USP. 69 p. (Dissertação de mestrado).

VENCOVSKY, R., N.A. VELLO, J.R. ZINSLY e C.R.M. GODOY, 197la • Aplicações das förmulas de predição na síntese de compostos de milho. Rel. Cient. Inst. Genética. ESALQ/USP, Piracica ba, $\underline{5}: 205-213$.

VENCOVSKY, R., J.R. ZINSLY e N.A. VELLO, 197lb. Homogeneização de um composto de milho. Rel. Cient. Inst. Genética. ESALQ/USP. Piracicaba, 5:214-222.

VENCOVSKY, R., 1978. Herança quantitativa. In: PATERNIANI, E., coord. Melhoramento e producão do milho no Brasil. Piracicaba/ESALQ, Marprint. cap. 5, p. 122-195.

VILLANO, R., 1966. Heterosis, accion genica y correlaciones de catorce variedades de maís en Colombia. Chapingo, México, Collegio de Post-Graduados, 70 p. (Tesis de Maestro).

WEBEL, O.D. e J.H. LONNQUIST, 1967. An evaluation of modified ear-to-row selection in a population of corn (Zea mays L.). Crop Sci. $\underline{7}: 651-655$.

WINKLEN, E.I.G., 1977. Seleção entre e dentro de famíláas de meios irmãos no milho (Zea mays L.) Composto Dentado Branco. Piracicaba, ESALQ/USP, 54 p. (Dissertação de Mestrado) 
ZINSLY, J.R., 1969. Estudo comparativo entre a seleção massal e seleção entre e dentro de familias de meios irmãos em milho (Zea mays L.). Piracicaba, ESALQ/USP. $52 \mathrm{p}$. (Tese de Doutoramento).

ZUBER, M.S., 1942. Relative efficiency of incomplete block designs using corn uniformity trial data. Agron. J. Madison, $34: 30-47$. 
.81.

APENDICE 
.82

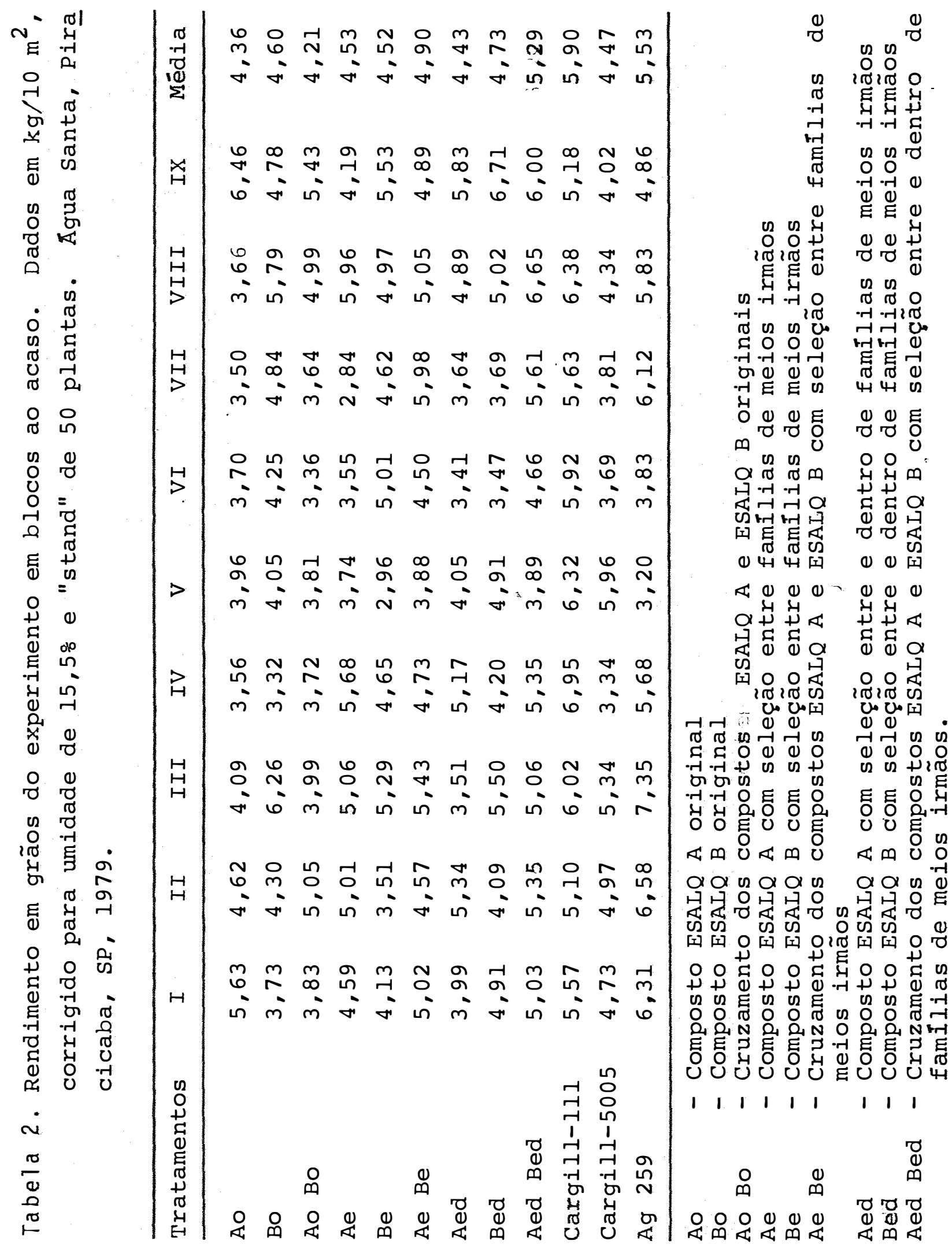




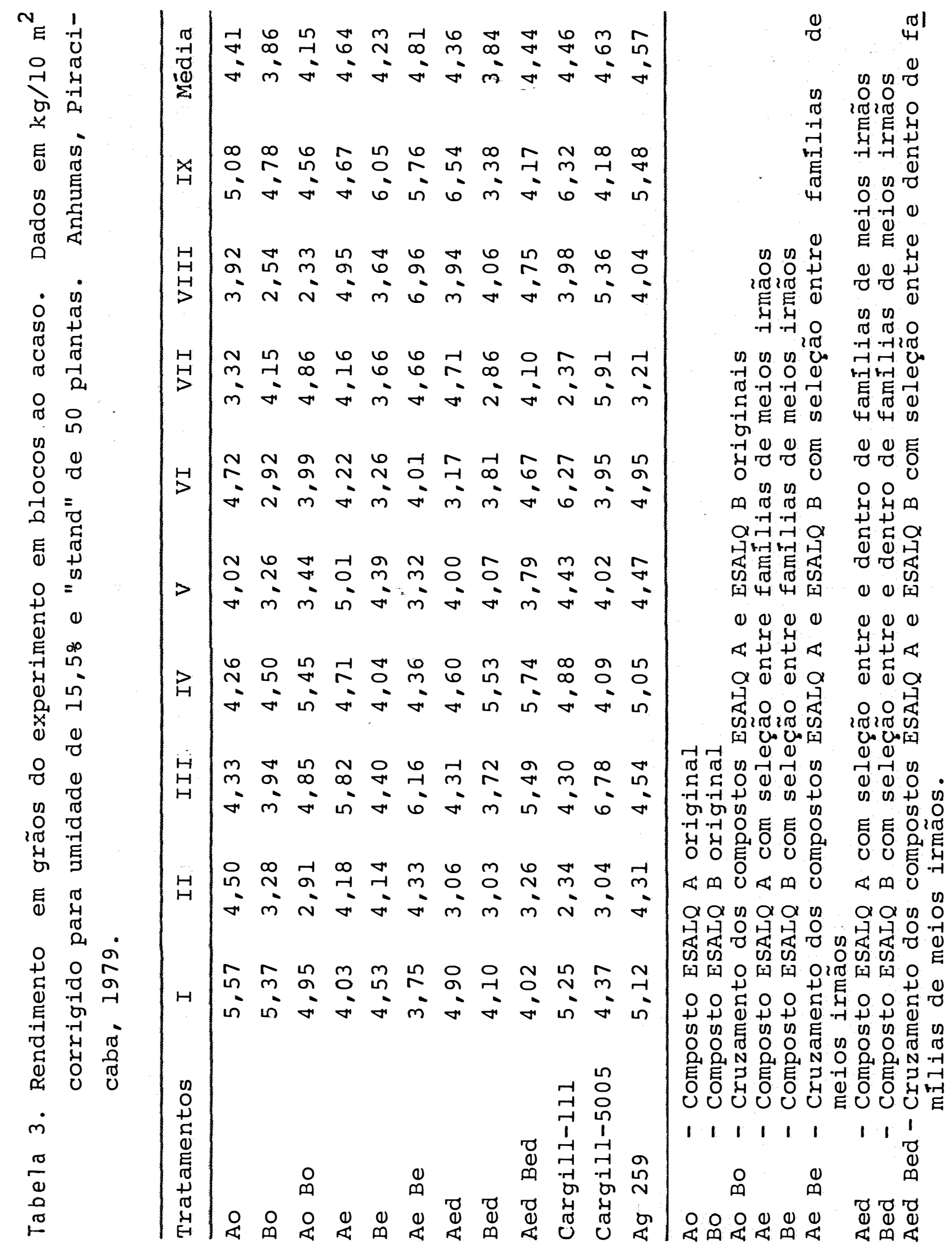




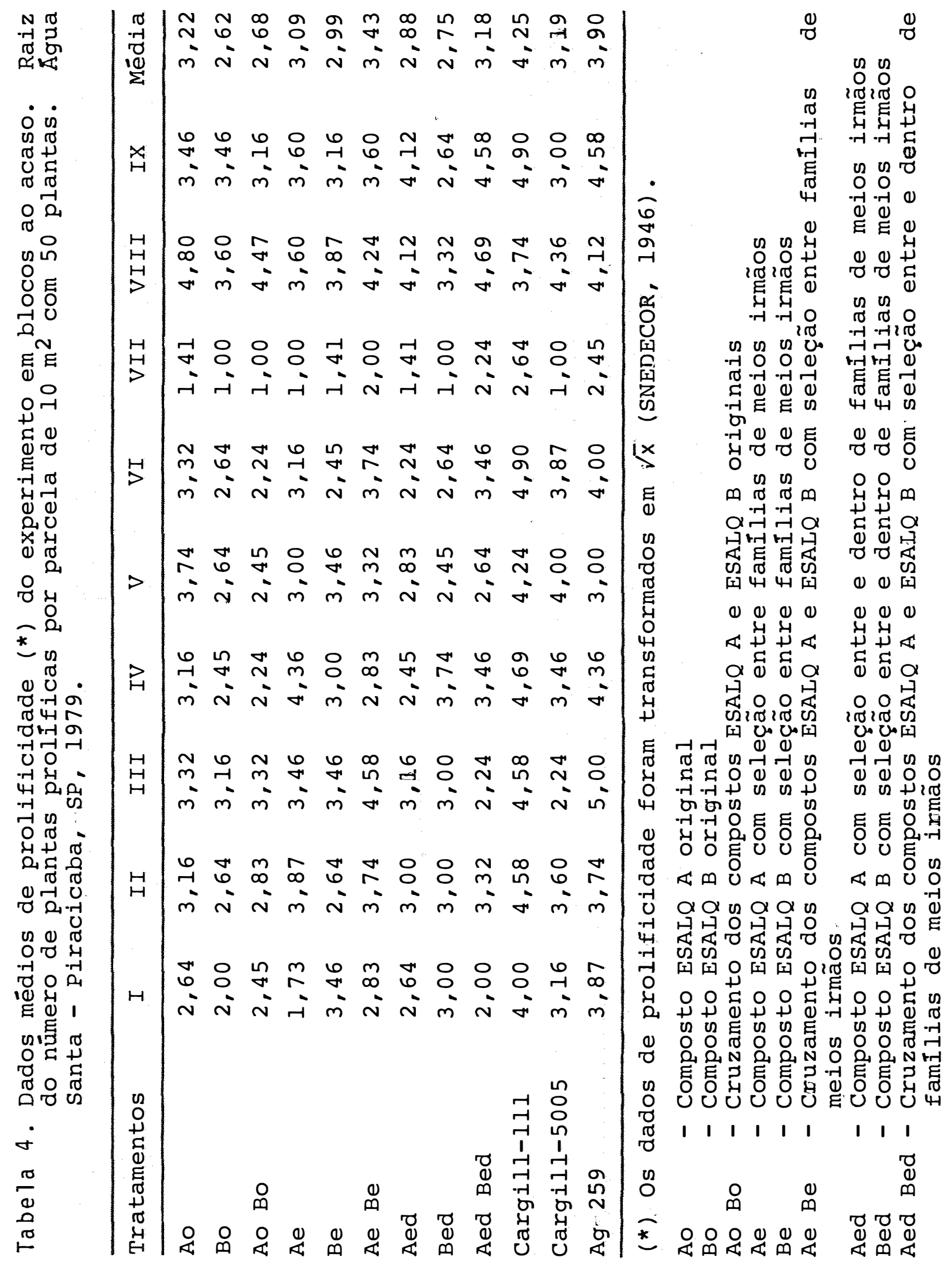




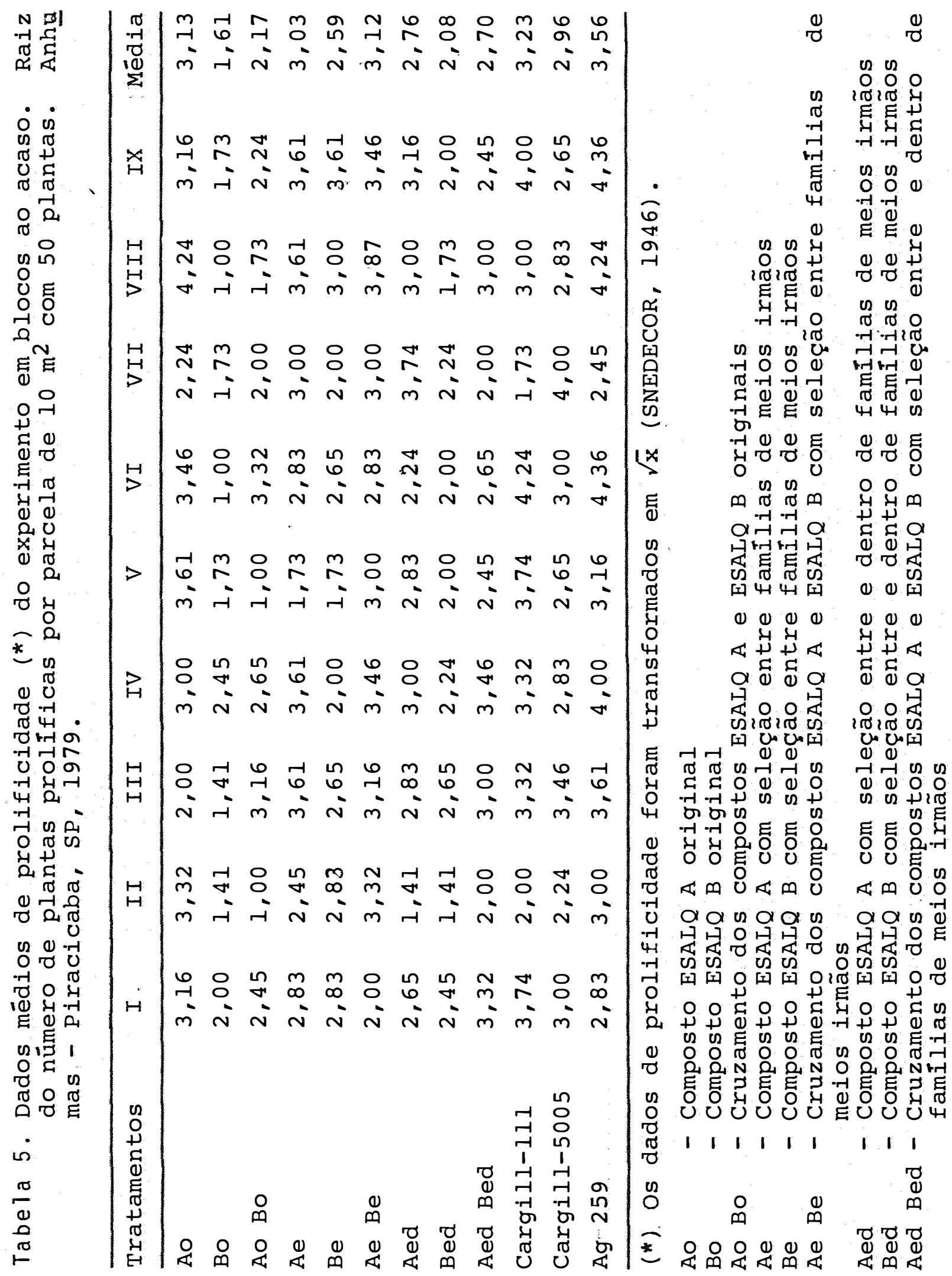




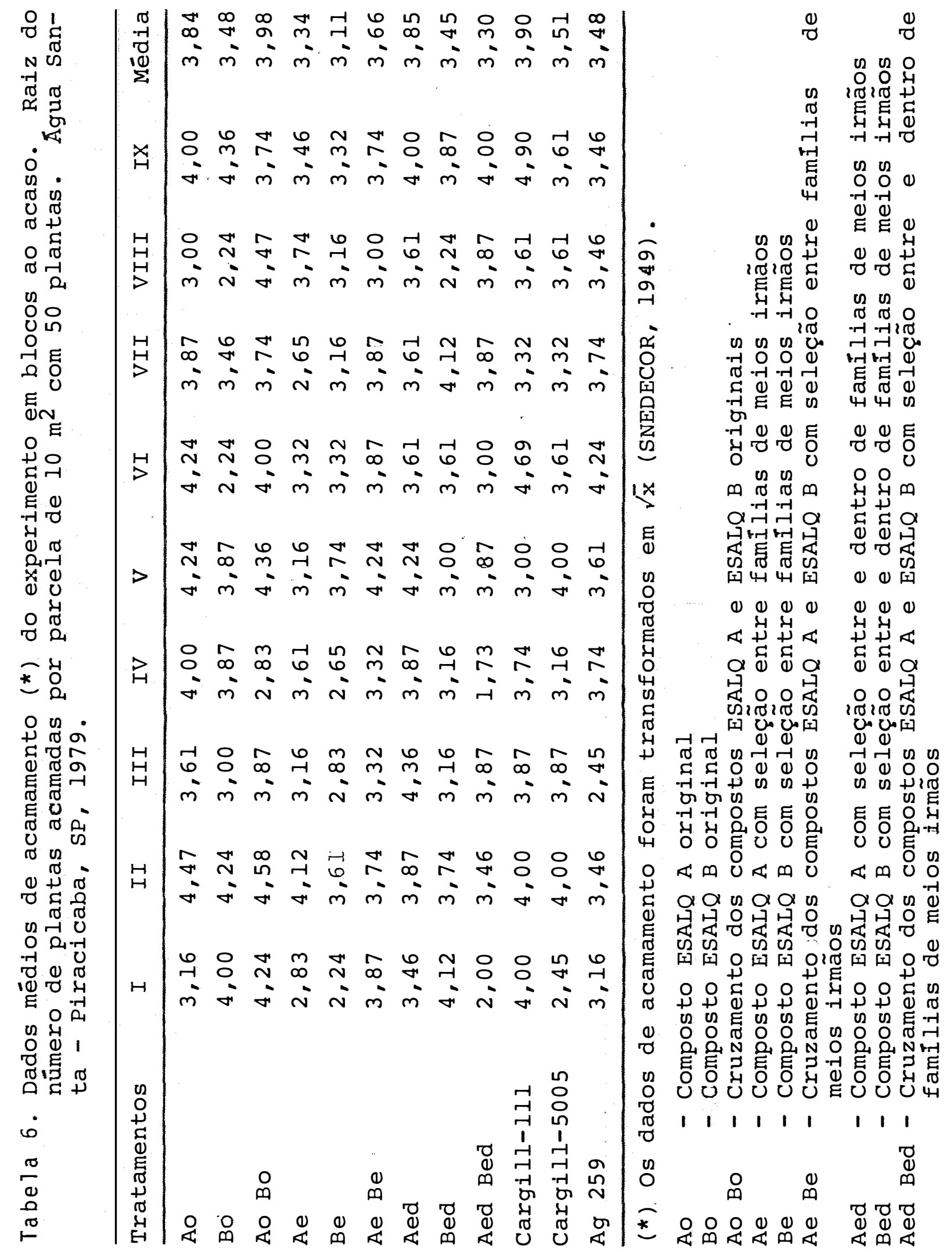




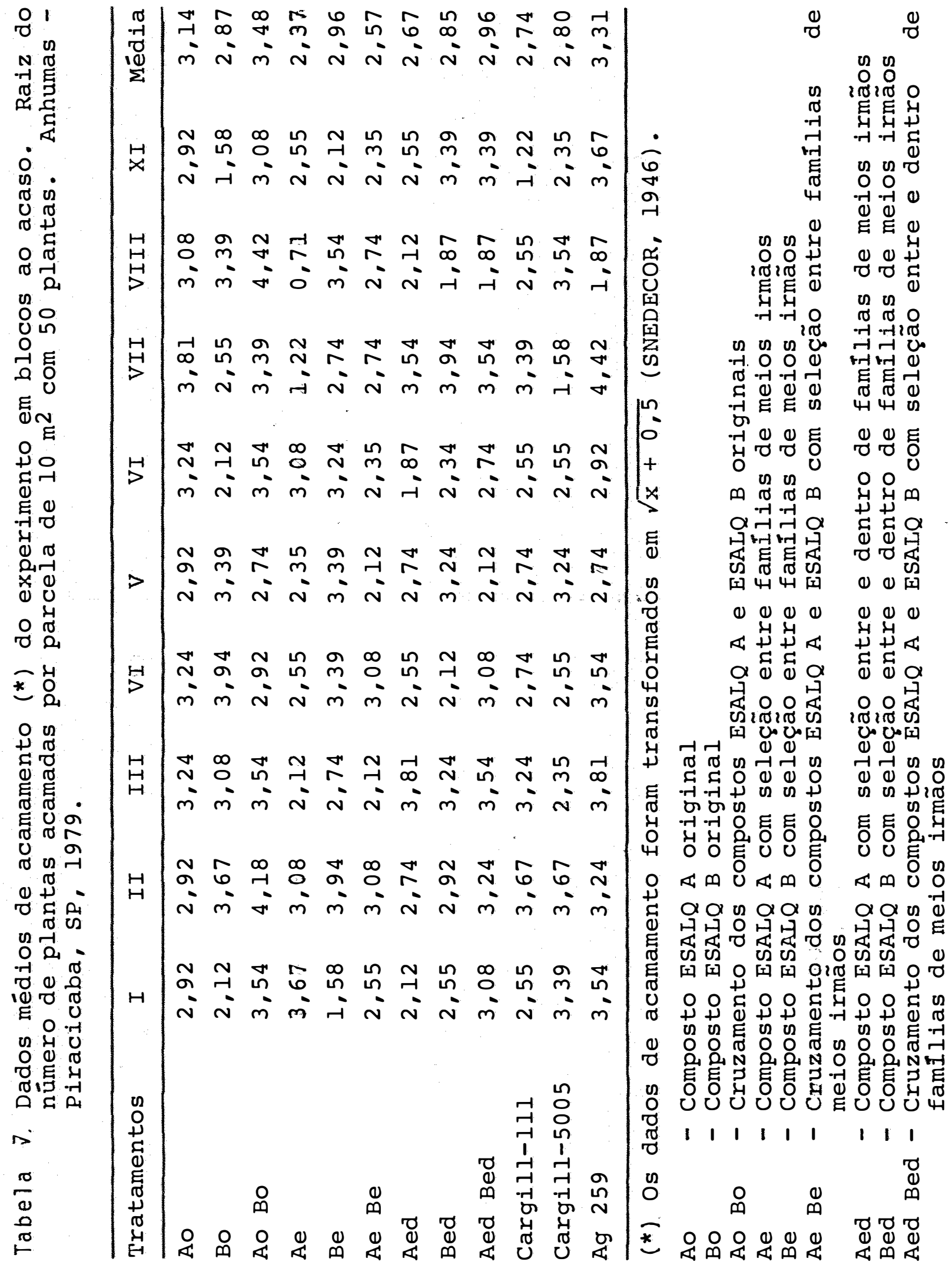




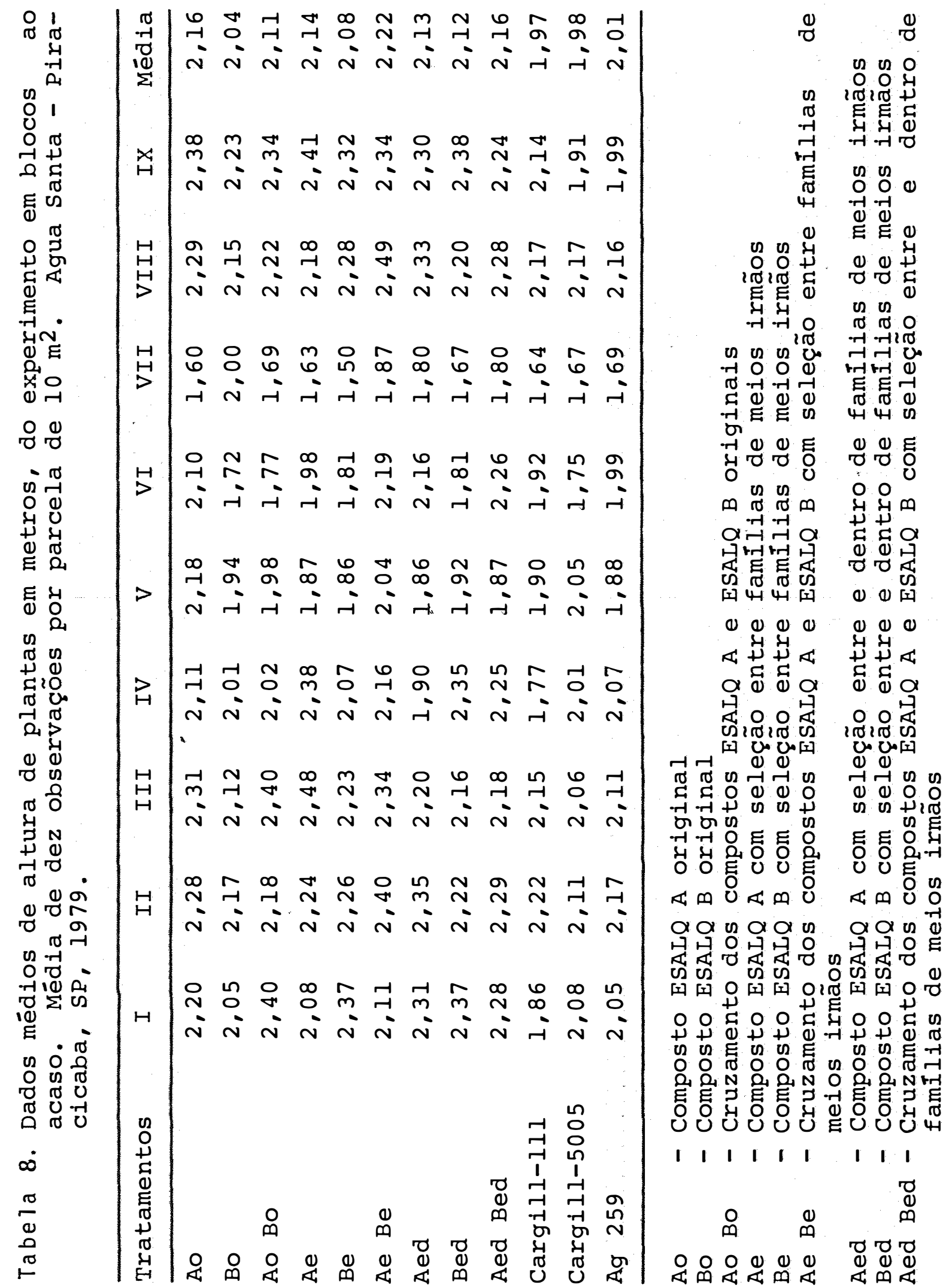




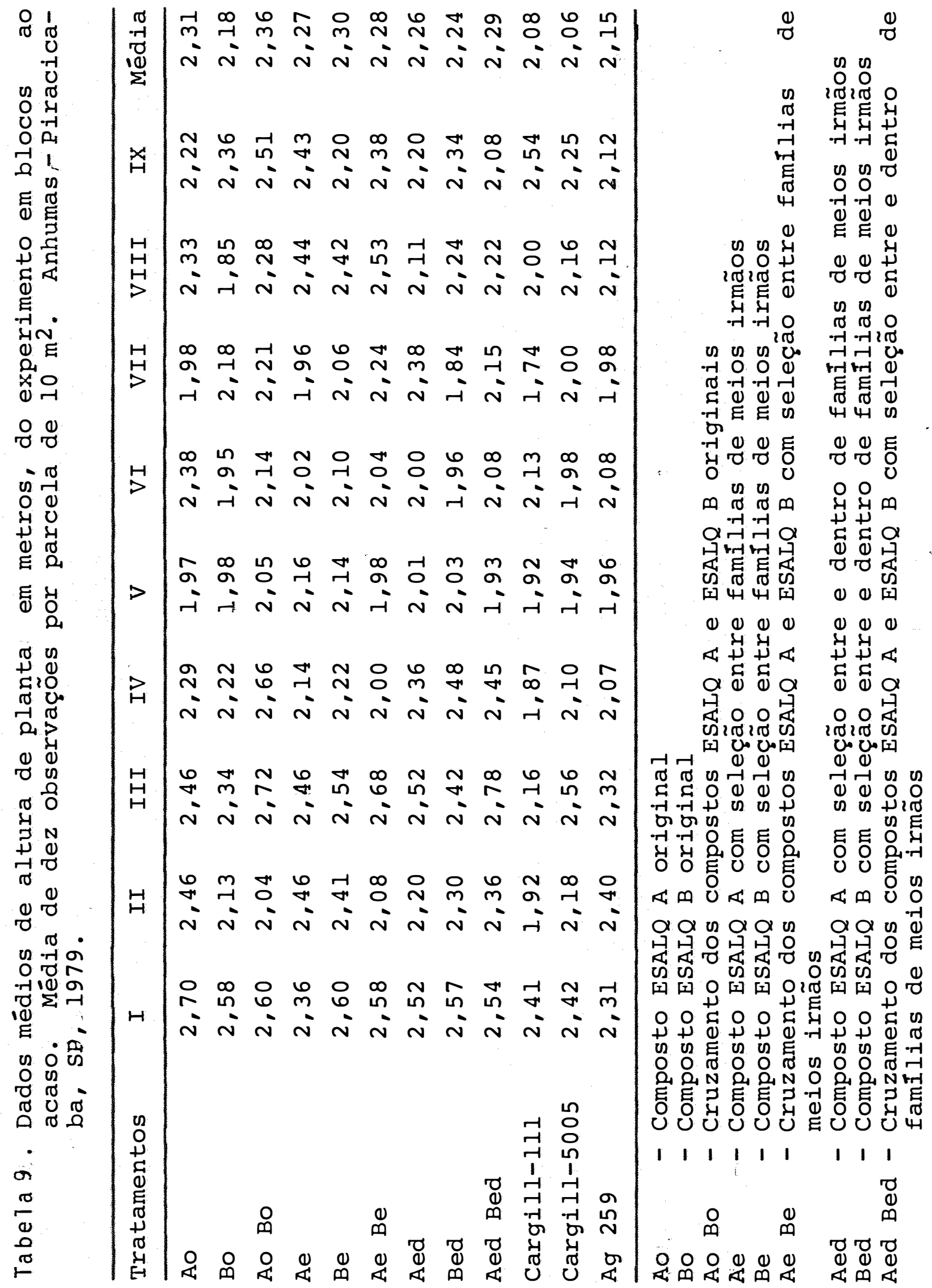




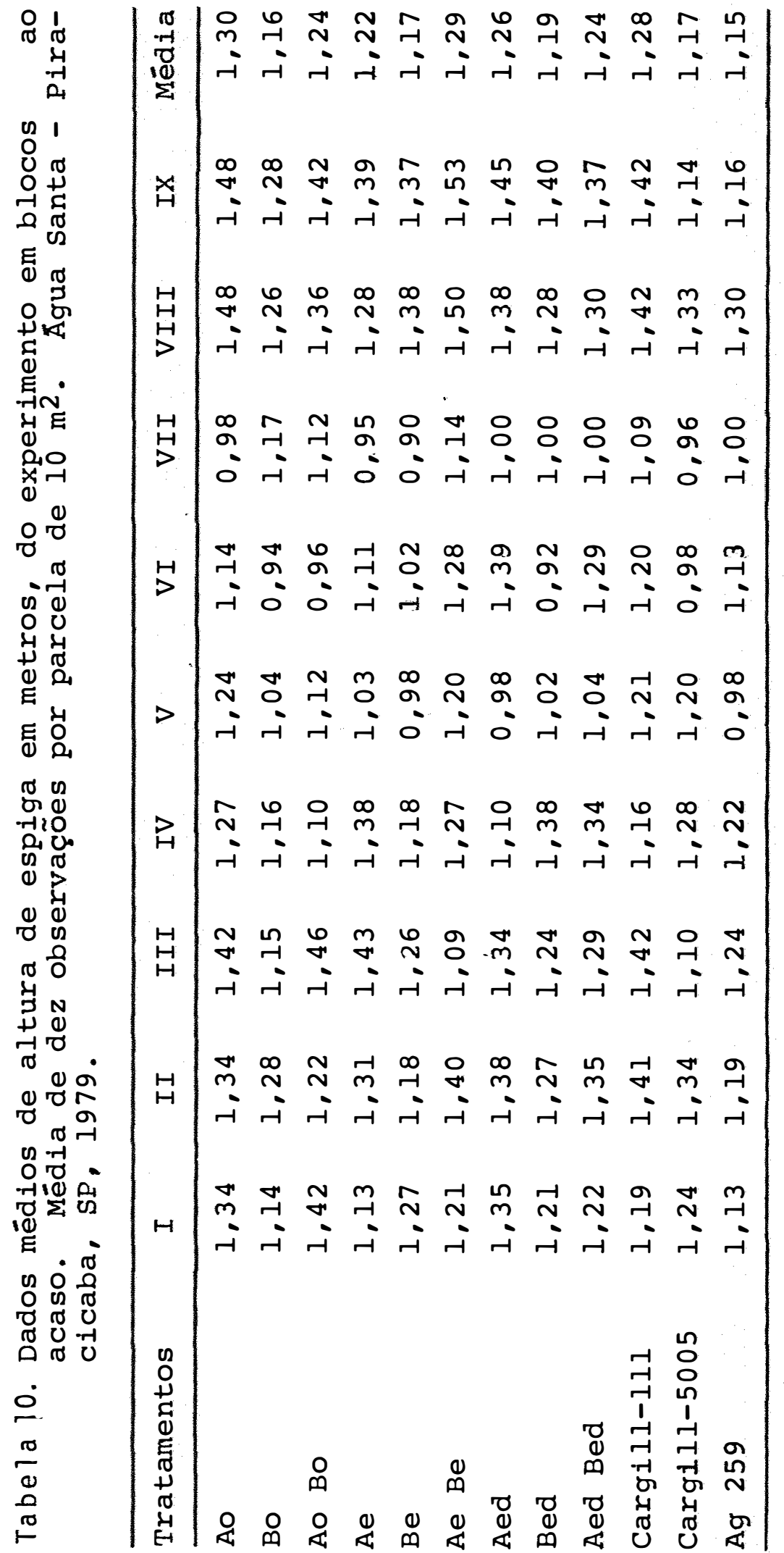

ठ্ठ

Q 02

0.0

范

E. है

- म्न द

ט 0

00

- 0 O

$\stackrel{\bigotimes}{\Xi}$

ต 0 म

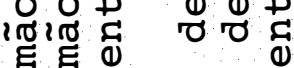

म न 0 वा ता 0

(2) 1000 नात्र

ज O O U

ब न्न न्न त्र हू हु

तE E WU

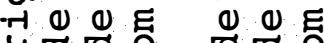

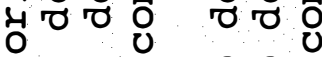

nn 0

$m$ ๙ 0 मे मे $m$

न्न न म

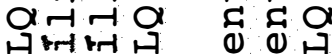

हू हू ठ ठ

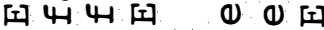

(1) $000 \quad 000$

$4 \stackrel{4}{4} 4$ 出出

व

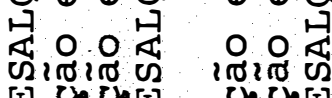

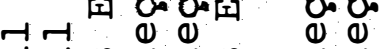

б

द 20000 0 000

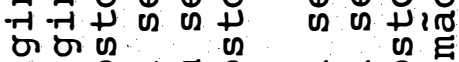

न्ने ह ह

O 0 E $U$ E $U U$ हू

«

a onan a an

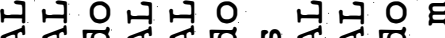
ব

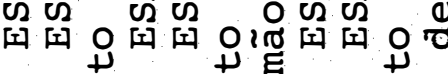

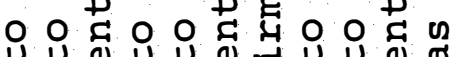
⿰冫 0 ○ 0 0

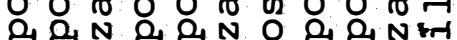

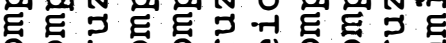
Оิ

$\begin{array}{lllllll}1 & 1 & 1 & 1 & 1 & 1 & 1\end{array}$

O

$m$ व

○ 


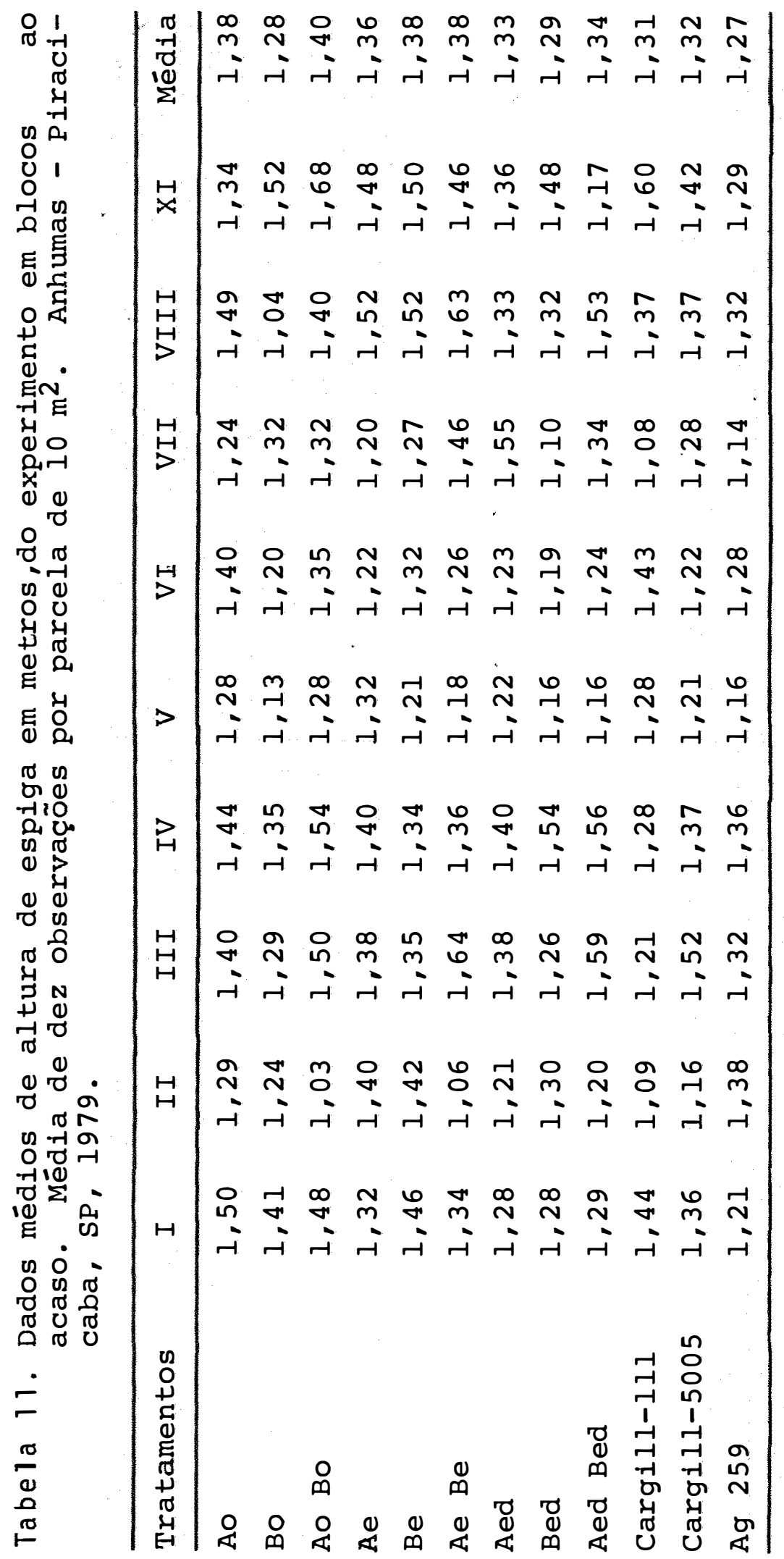

व

ก 02

2 2020

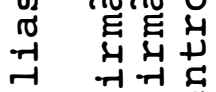

नन्न क्ष

थ 02

웅

(1) Е Е

صू 号

मुन्म 0 ति

$2 \pi$ 开

थट थट

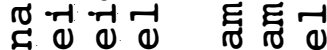

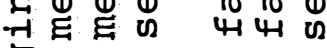

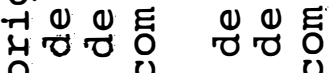

म

प्रे्मे

वनन व स्त्व

जमrनt

EE

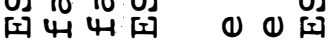

1) 0000000

《式过出式反

व है

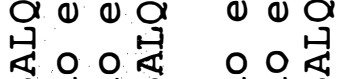

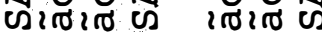

-1 되 어요다

नै न1 (1) 0

Uण口

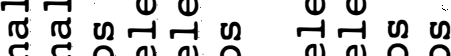

न न

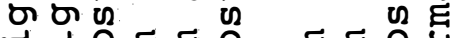

㢤

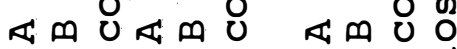

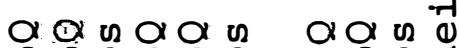

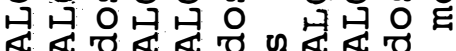

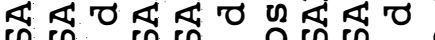

जी W़ि

证

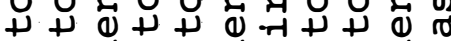

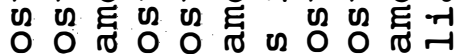

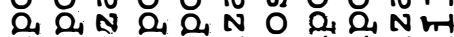
芩

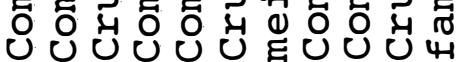

$\begin{array}{lllllllll}1 & 1 & 1 & 1 & 1 & 1 & 1 & 1\end{array}$

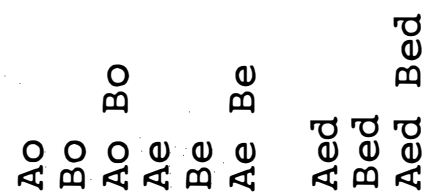


Tabela 12. Quadrado médio, teste $F$, média e coeficiente de variação da análise dos dados das características pro dução, prolificidade, acamamento, altura de planta e espiga. Agua Santa - Piracicaba, SP, 1979.

\begin{tabular}{llllll}
\hline $\begin{array}{l}\text { Caracteris- } \\
\text { ticas }\end{array}$ & Produção & $\begin{array}{c}\text { Prolifi } \\
\text { cidade }\end{array}$ & & $\begin{array}{c}\text { Altura } \\
\text { de } \\
\text { planta }\end{array}$ & $\begin{array}{c}\text { Altura } \\
\text { de } \\
\text { espiga }\end{array}$ \\
QM & 2,4478 & 2,1327 & 0,6638 & 0,0535 & 0,0259 \\
F & $3,58 * *$ & $7,47 * *$ & $2,36 * *$ & $3,39 * *$ & $2,70 * *$ \\
Média (*). & 4,78 & 10,13 & 12,78 & 2,09 & 1,22 \\
C.v. (8) & 17,3 & 16,9 & 14,8 & 6,0 & 8,0 \\
\end{tabular}

(*). As médias das caracteristicas foram tomadas em: $\mathrm{kg} / 10 \mathrm{~m}^{2}$ para produção corrigida para "stand" e umidade; no de plan tas prolificas/parcela de $10 \mathrm{~m}^{2}$; no de plantas acamadas/ parcela de $10 \mathrm{~m}^{2}$; média de 10 observações/parcela de $10 \mathrm{~m}^{2}$ para altura de planta e espiga. 
labela 13. Quadrado médio, teste F, média e coeficiente de variação da anālise dos dados das características pro dução, prolificidade, acamamento, altura de planta e espiga. Anhumas - Piracicaba, SP, 1979.

\begin{tabular}{|c|c|c|c|c|c|}
\hline $\begin{array}{c}\text { Caracteris } \\
\text { ticas }\end{array}$ & Produção & $\begin{array}{l}\text { Prolifi } \\
\text { cidade }\end{array}$ & Acamamento & $\begin{array}{l}\text { Altura } \\
\text { de } \\
\text { planta }\end{array}$ & $\begin{array}{c}\text { Altura } \\
\text { de } \\
\text { espiga }\end{array}$ \\
\hline$Q M$ & 0,8203 & 2,7899 & 0,8607 & 0,0568 & 0,0159 \\
\hline $\mathrm{F}$ & $1,13^{\mathrm{ns}}$ & $8,07 * *$ & $2,05 *$ & $2,51 * \star$ & $1,19^{n s}$ \\
\hline Média (*). & 4,37 & 7,54 & 8,38 & 2,24 & 1,34 \\
\hline C.V. ( (\%) & 19,5 & 21,4 & 22,4 & 6,7 & 6,7 \\
\hline
\end{tabular}

(*). As médias das caracteristicas foram tomadas em: $\mathrm{kg} / 10 \mathrm{~m}^{2}$ para produção corrigida para "stand" e umidade; no de plan tas prolificas/parcela de $10 \mathrm{~m}^{2}$; no de plantas acamadas/ parcela de $10 \mathrm{~m}^{2}$; média de 10 observações/parcela de $10 \mathrm{~m}^{2}$ para altura de planta e espiga. 
Tabela 1.4. Soma de quadrados totais dos tratamentos das aná lises simples para produção corrigida para "stand" e umidade desdobrados em: entre seleções $A$; entre seleções $B$; entre seleções $A B$; entre grupos; entre testemunhas e populações"vs". testemunhas.

Fonte de Variação G.L. $\frac{\text { Agua Santa }}{\mathrm{QM}} \underset{\mathrm{F}}{\frac{\text { Anhumas }}{\mathrm{QM}}} \frac{\mathrm{F}}{\mathrm{Q}}$

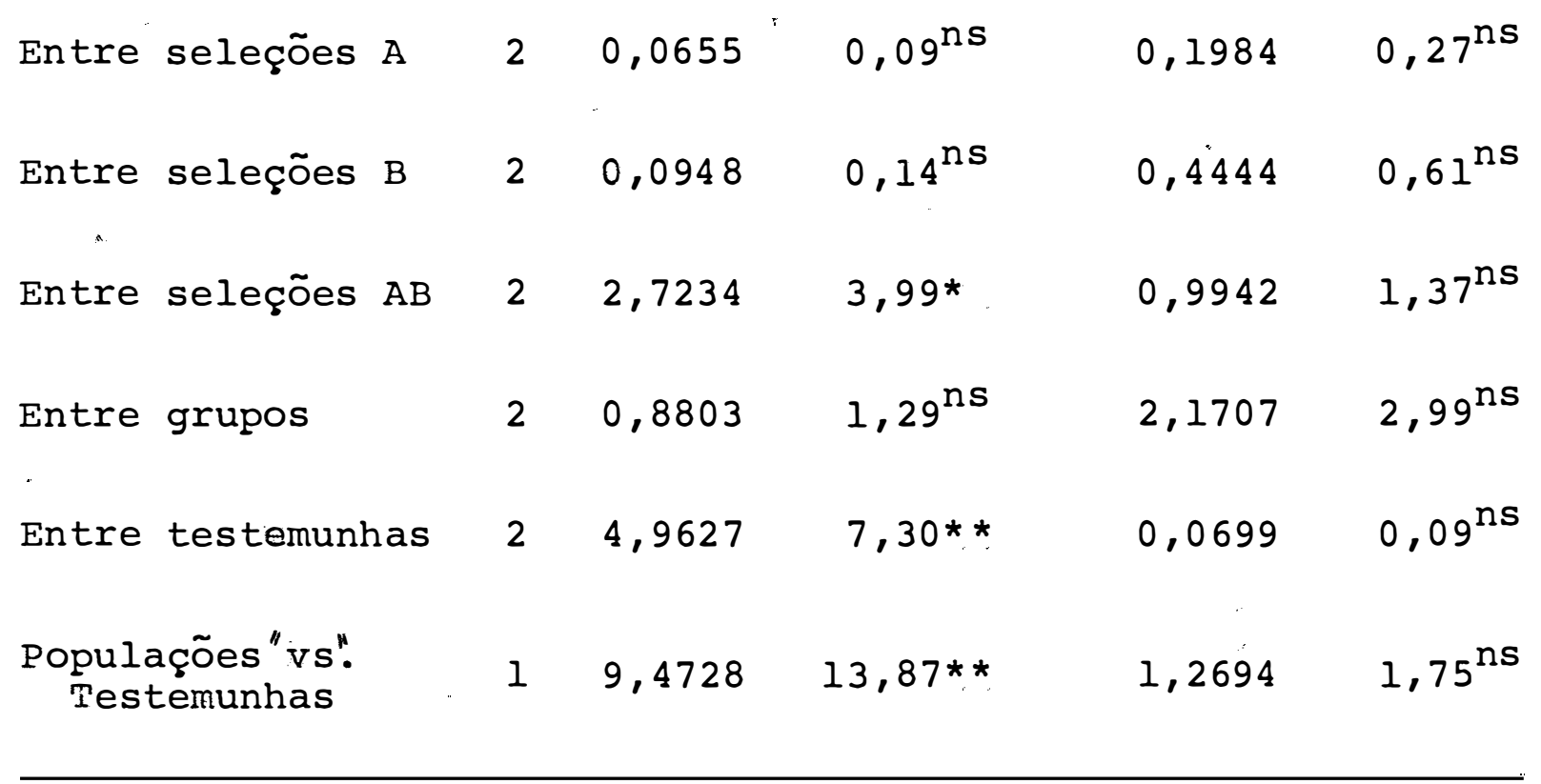




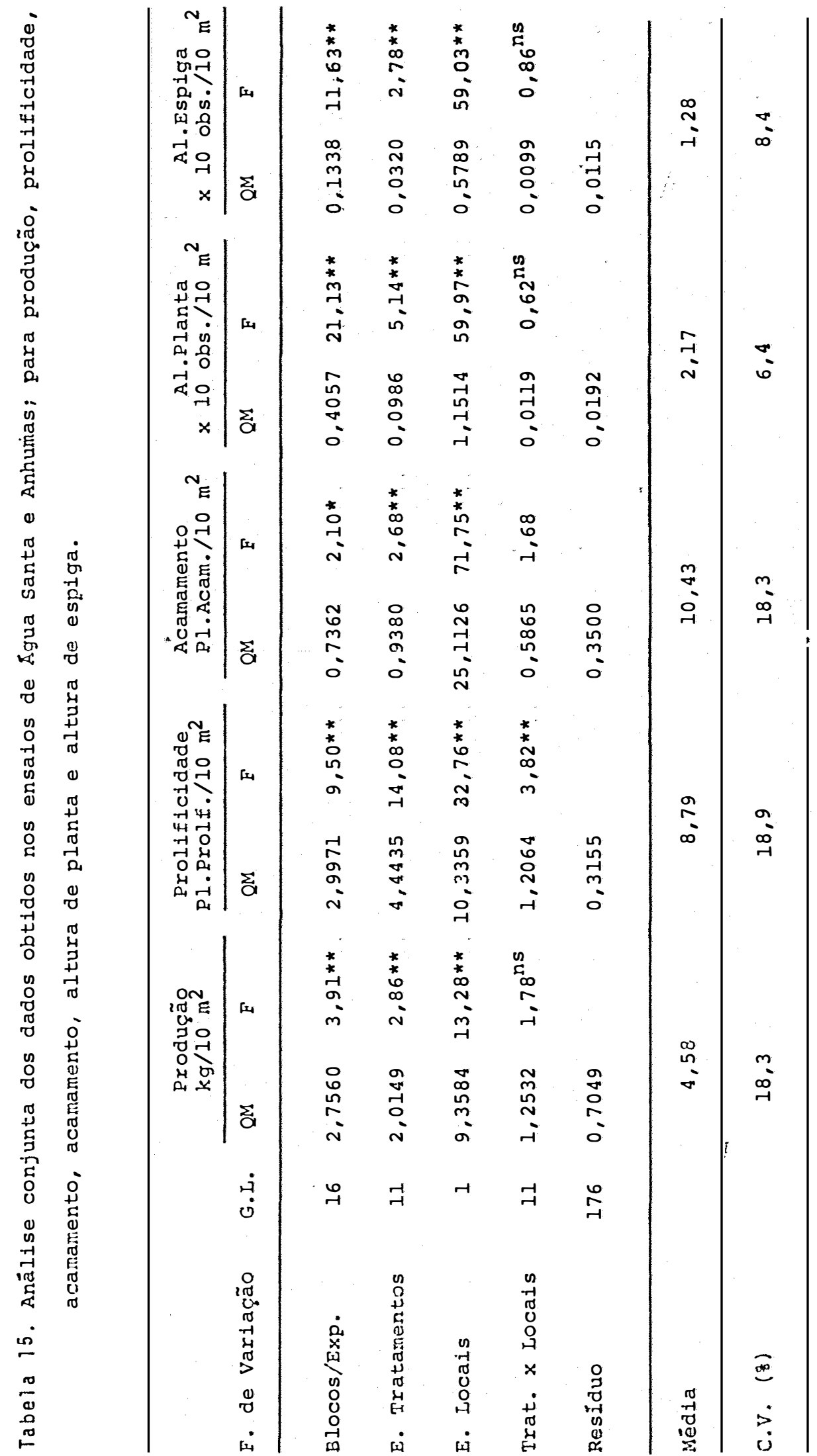




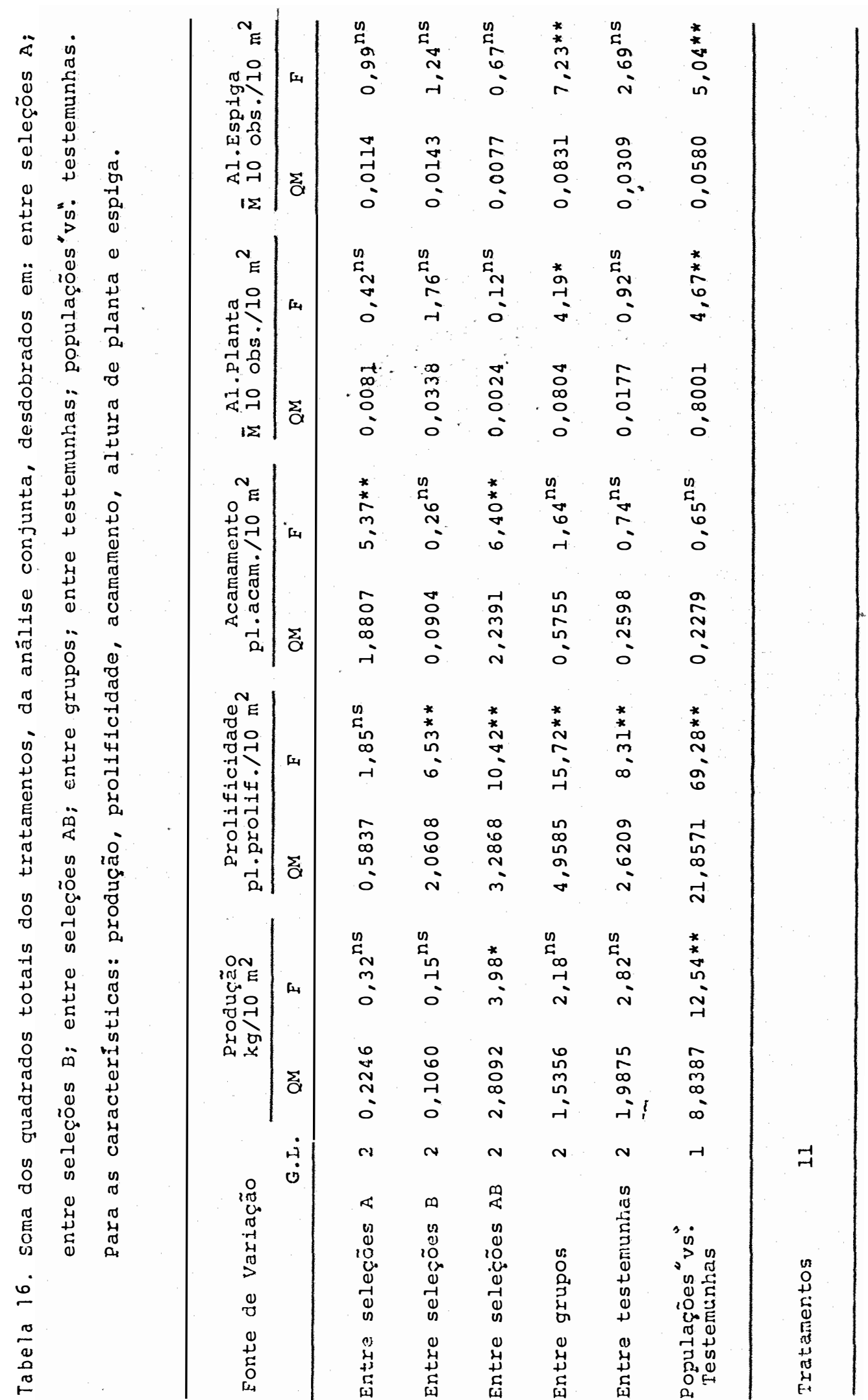




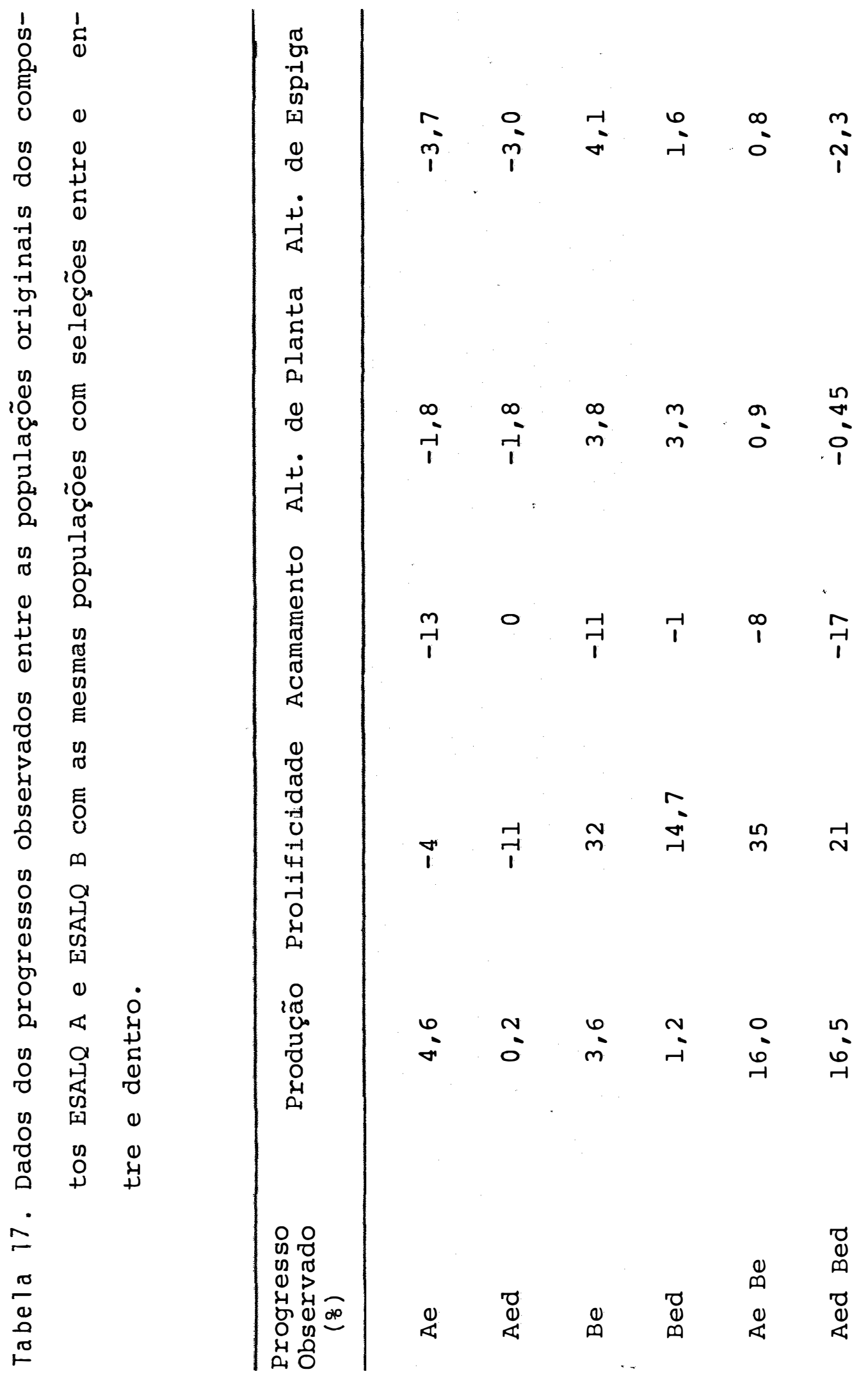




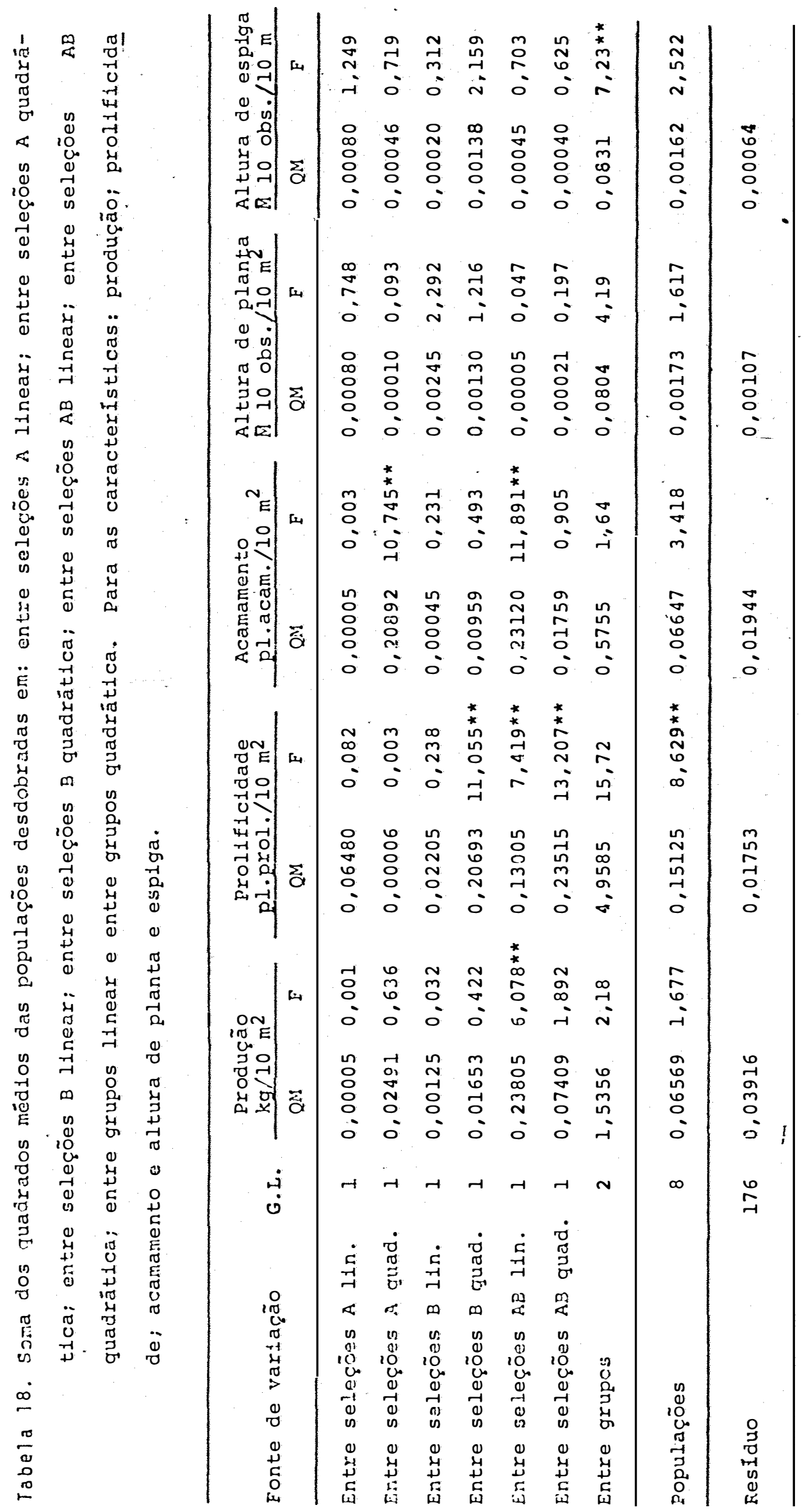


Tabela.19. Cálculo dos progressos médios, com base nos métodos dos quadrados mínimos. Teste de hipöteses.

\begin{tabular}{|c|c|c|c|c|}
\hline F.V. & G.I. & $Q M .10^{-2}$ & F & $\begin{array}{c}P \\
(5-10 \%)\end{array}$ \\
\hline Tratamentos & 8 & 6,4500 & 1,647 & \\
\hline Parâmetros (*) & 5 & 8,2100 & 2,096 & \\
\hline Desvios do Modelo & 3 & 3,5167 & $<1$ & \\
\hline \multicolumn{5}{|l|}{ Hipöteses } \\
\hline$\overline{\mathrm{A}} \mathrm{o}$ "vs." $\overline{\mathrm{B}} \mathrm{O}$ & 1 & 107,9600 & $27,567 * *$ & \\
\hline$G_{A}$ "vs." $G_{B}$ & 1 & 0,0422 & $<1$ & \\
\hline Heterose ( $\mathrm{AO} \times \mathrm{BO}$ ) & 1 & 0,4600 & $<1$ & \\
\hline G heterose & 1 & 14,4900 & 3,700 & ** \\
\hline$G_{(A, B)}$ & 1 & 0,1322 & $<1$ & \\
\hline Resíduo & 176 & 3,9162 & & \\
\hline
\end{tabular}

(*). Parâmetros: $\mathrm{AO}, \mathrm{BO}, \mathrm{B}_{\mathrm{A}}, \mathrm{G}_{\mathrm{B}^{\prime}}$, heterose, $G$ heterose, estima$\operatorname{dos}(t / h a)$. 


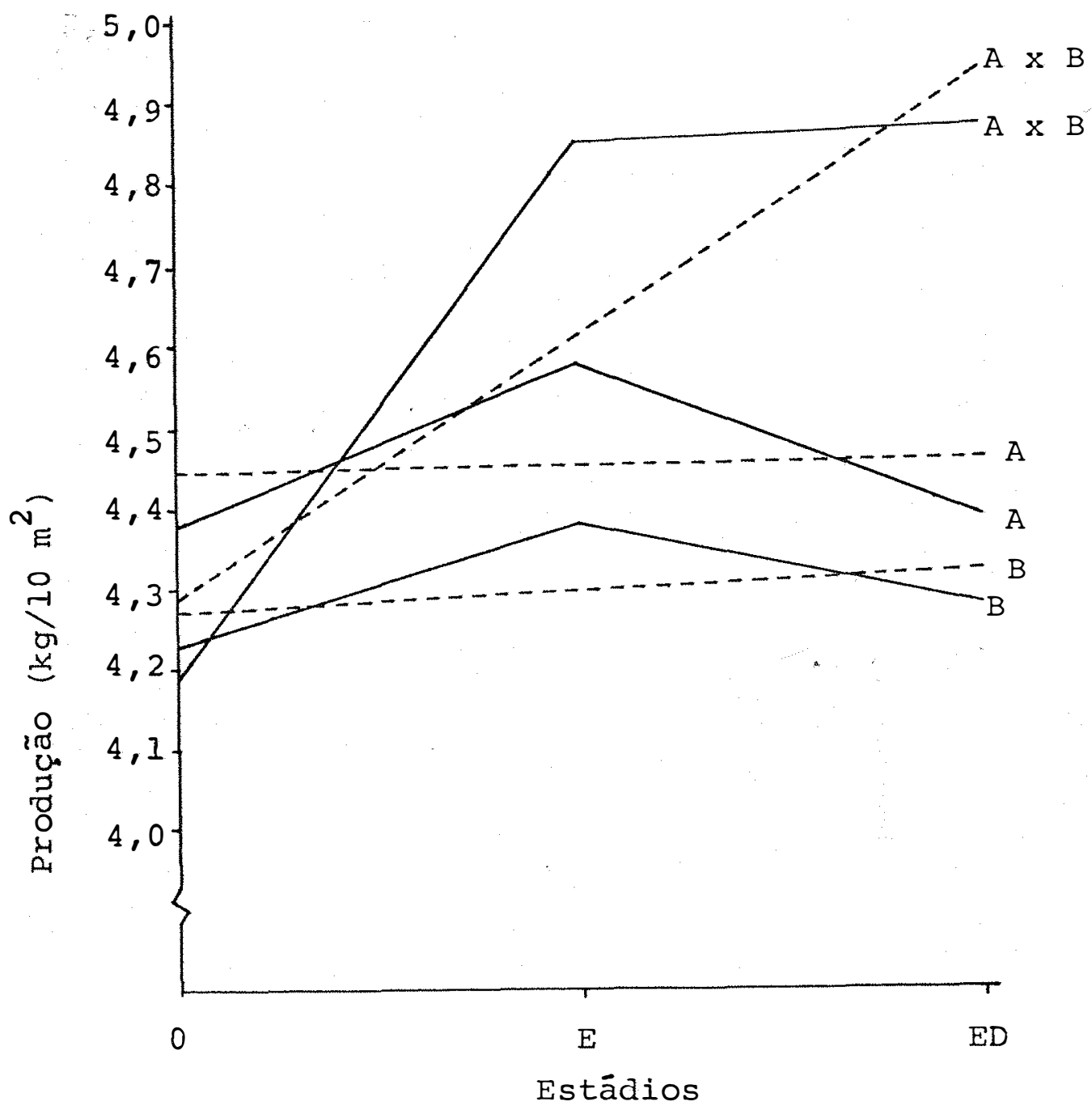

Figura 1. Efeito da seleção entre e seleção entre e dentro dos compostos ESALQ A e ESALQ B, para o caráter produção. Curvas do progresso observado e estimado. 